\title{
The Veikkola granite area in southern Finland: emplacement of a 1.83-1.82 Ga plutonic sequence in an extensional regime
}

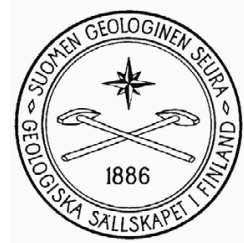

\author{
Mikko Nironen $^{1) *}$ and Matti Kurhila ${ }^{2)}$ \\ 1) Geological Survey of Finland, P.O. Box 96, FI-02151 Espoo, Finland \\ 2) Department of Geology, P.O. Box 64, FI-00014 University of Helsinki
}

\begin{abstract}
Four granite intrusions and coeval small enderbite intrusions, belonging to the lateorogenic ( 1850 - $1820 \mathrm{Ma}$ ) magmatism of the Svecofennian orogeny, are described in the Veikkola area of southern Finland. The granites are leucocratic, heterogeneous and characterized by abundant garnet. The oldest granite is layered whereas the younger ones are more homogeneous. Geochemically the granites are peraluminous and have high contents of $\mathrm{SiO}_{2}$ (7I - 76 wt.\%). Their major and minor element composition varies significantly but the REE patterns are fairly similar. Garnet mainly crystallized from melt but some garnet in the granites may be restitic. Garnet composition is relatively constant implying slow equilibration with the melt.

In addition to garnet-bearing felsic layers in the oldest granite, the granites are crosscut by garnet-bearing dikes and veins. The layers, dikes and veins are higher in REE and Fe/Mg than the host granites and are considered partial melts from the granites. The abundant garnet in the felsic layers, dikes and veins crystallized from melt. Thermobarometry calculations indicate $3.5-5 \mathrm{kbar}$ and $\sim 650-700^{\circ} \mathrm{C}$ estimates for crystallization of the felsic layers in the oldest granite whereas the host granite yields $\sim 1.5 \mathrm{kbar}$ higher pressure.

The granites were probably derived by dehydration melting of layered, metagreywackedominated rocks. Melting was fluid-absent both during generation of the granites and during formation of the felsic layers, dikes and veins. The oldest granite (I850 Ma) was emplaced at mid-crustal depth before extensional deformation. Layering in the oldest granite is regarded as the result of deformation-induced remelting of the host granite at a higher crustal level, during protracted extension and progressive regional metamorphism. The other three granites and the enderbite were emplaced at a late stage of extension, at or close to the peak of metamorphism $(1.83-1.82 \mathrm{Ga})$.
\end{abstract}

Key words: granites, gneisses, structural analysis, geochemistry, garnet group, electron probe data, P-T conditions, Proterozoic, Paleoproterozoic, Veikkola, Finland

*Corresponding author email: mikko.nironen@gtk.fi 


\section{Introduction}

The Svecofennian orogeny in the present Fennoscandian Shield covers an age range of $1.9-1.8 \mathrm{Ga}$. The orogenic granitoid rocks have traditionally been divided into synorogenic, lateorogenic, and postorogenic with respect to orogenic movements (e.g. Simonen, 1980). Although the concept of Svecofennian orogeny has changed by the application of the plate tectonic concept (see Lahtinen et al., 2005), the old division has still been used albeit with new platetectonic connotations (Nironen, 2005). The synorogenic rocks are $1.89-1.87 \mathrm{Ga}$ old and gabbroic to predominantly granodioritic and granitic in composition. A group of lateorogenic granites $(1.84-1.82$ Ga; Huhma, 1986; Suominen, 1991) constitute the Late Svecofennian granite-migmatite zone (Ehlers et al., 1993) that crosscuts supracrustal rocks as well as synorogenic plutonic rocks as an ENE-WSW trending belt (Fig. 1). The emplacement of the lateorogenic granites is associated with peak of high-T/low-P metamorphism that in places reached granulite grade (Väisänen et al., 2002; Mouri et al., 2005). Postoro- genic $(1.81-1.79 \mathrm{Ga})$ intrusions are small mafic to felsic plutons and dikes with shoshonitic affinities within the Late Svecofennian granite-migmatite zone (e.g. Vaasjoki, 1996; Eklund et al., 1998).

The granites within the Late Svecofennian granite-migmatite zone vary in appearance: they may be fairly homogeneous porphyritic rocks, even-grained rocks with ghost-like remnants of older rocks, or contain abundant felsic veins that give the rock a layered appearance; each of these may gradually merge into migmatitic host supracrustal rocks (e.g. Härme, 1965; Ehlers et al., 1993). Studies in the western part of the Late Svecofennian granite-migmatite zone have led to a model of emplacement for the granites that includes subhorizontal movements in an overall transpressional tectonic regime (Ehlers et al., 1993).

The plate-tectonic model of Lahtinen et al. (2005) includes accretion of an arc complex to another one in the area of southern Finland, producing subhorizontal deformation structures, amphibolite facies peak metamorphism and emplacement of synorogenic rocks along these structures during $1.89-1.87 \mathrm{Ga}$. A period of extension at $1.86-1.85$ Ga followed

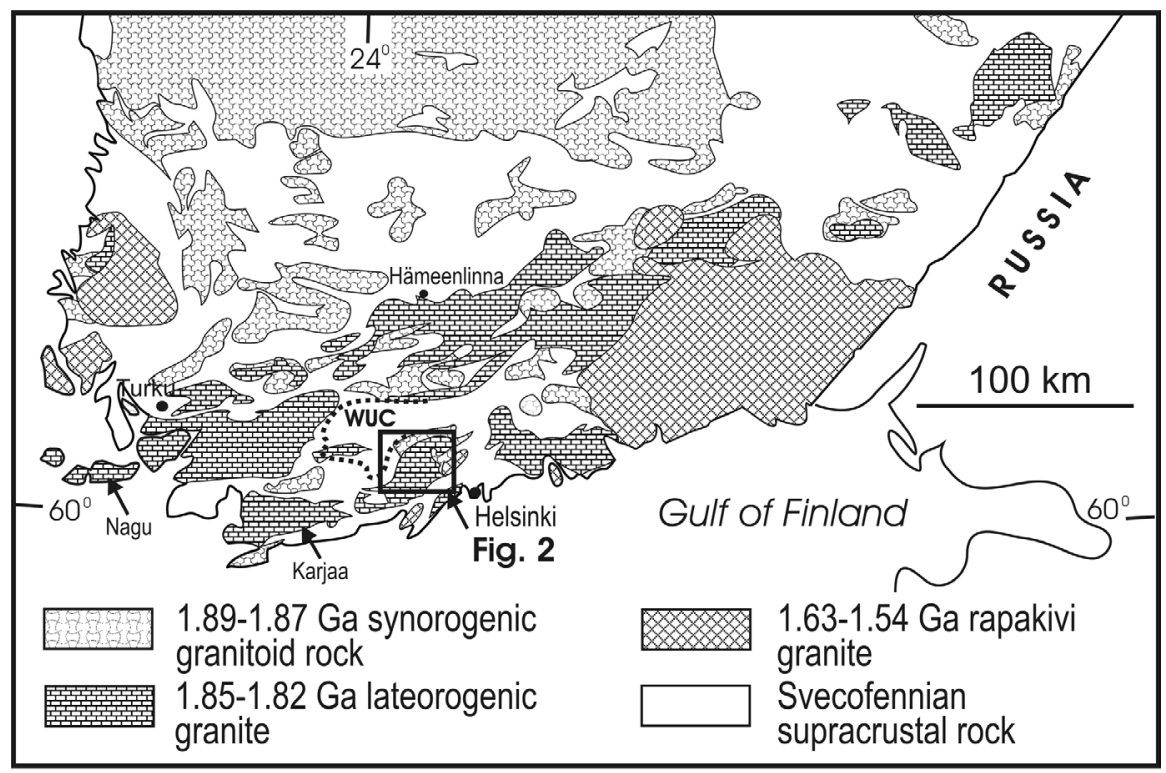

Fig. I. Geological map of southern Finland (modified from Korsman et al. 1997). The lateorogenic granites define the ESE-WNW trending Late Svecofennian granite-migmatite zone.WUC = West Uusimaa Complex of granulite facies assemblages. Dotted line delimits the "orthopyroxene-in" area (Schreurs \& Westra, 1986). 
synorogenic magmatism. A second convergent event caused folding of these structures into an upright position. High heat flow during this stage caused largescale anatexis of the crust in southern Finland at 1.84 - $1.82 \mathrm{Ga}$, giving rise to metamorphism that in places reached granulite grade. The lateorogenic granites were emplaced as the result of anatexis.

The reason for the diverse mode of occurrence of the lateorogenic granites, especially for the layering, has remained unclear. In general, layering in igneous rocks has been attributed to gravitational settling, deposition from magmatic turbidity currents, convection, shear flow, liquid immiscibility, metasomatism of sedimentary rocks, and metamorphic differ- entiation; for layering in granitoid rocks shear flow, streaked-out heterogeneities and partial assimilation have been suggested (see Clarke \& Clarke, 1998). Edelman (1972) described layered granites in the Nagu area of southwestern Finland (Fig. 1) and interpreted the layering as the result of granitization of a sedimentary rock with primary bedding. Recently Stålfors \& Ehlers (2006) interpreted the layering in the Nagu granite as the result of repeated injection of small melt pulses.

Kurhila et al. (2005) showed that the age spread in the lateorogenic granites is larger than previously considered, containing $1.85 \mathrm{Ga}$ and $1.82 \mathrm{Ga}$ granites in the Veikkola area (Fig. 2). This age spread led

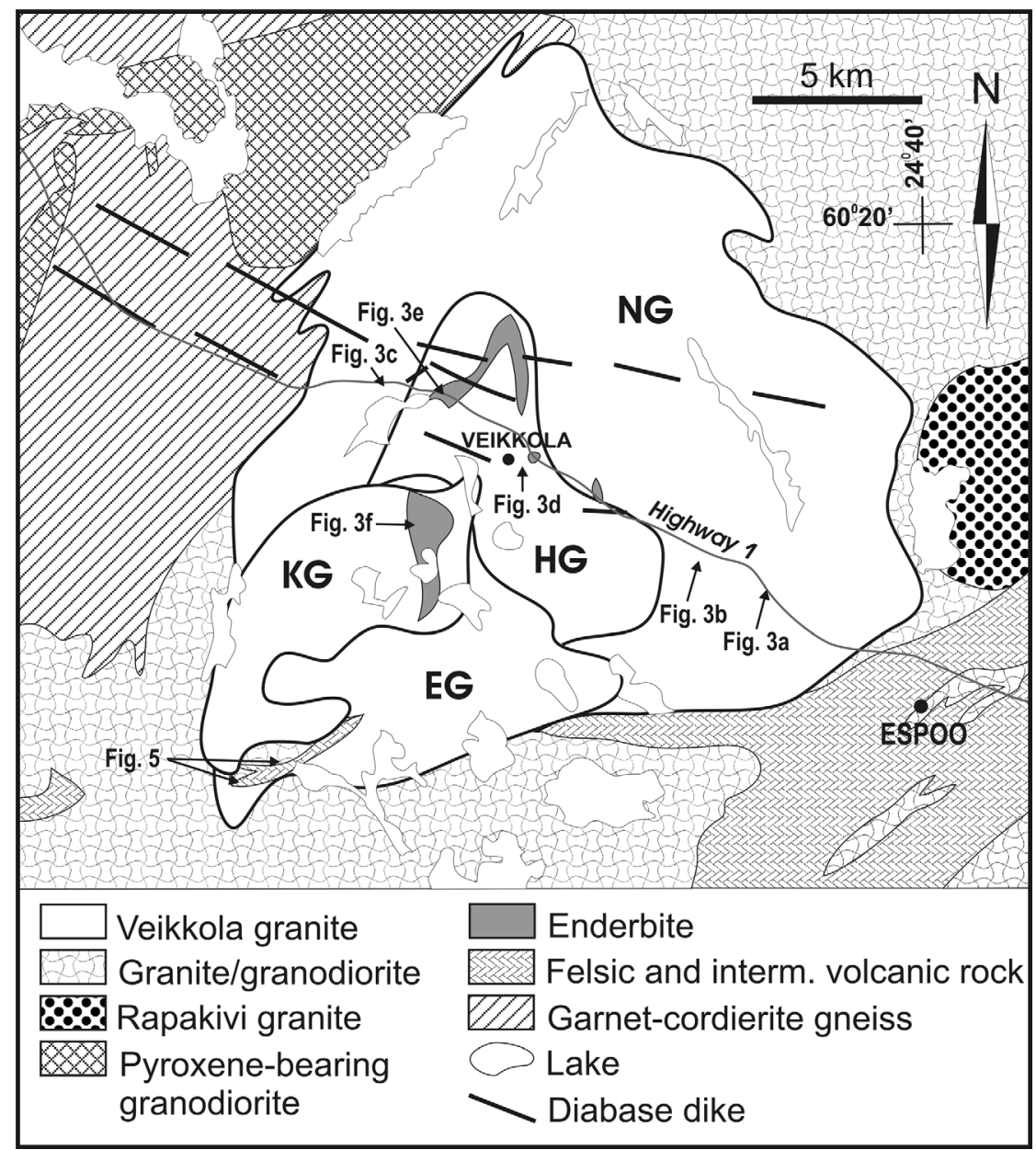

Fig. 2. Lithological map of the Veikkola area (modified from Laitala, 1960, 1994). NG = Nuuksio granite, HG = Haapajärvi granite, $E G=$ Evitskog granite, $K G=$ Kylmälä granite. 
to the conclusion that the seemingly homogeneous granite area consists of at least two separate intrusions. On the basis of detailed field studies we have been able to discern four granite types in the Veikkola area which conform in the order of emplacement with the previously presented age data. We discuss their geochemical characteristics, reason for layering, and tectonic regime during emplacement.

\section{Lithology}

\section{I. Host rocks}

The Veikkola granites are surrounded by granitoids as well as various gneisses (Fig. 2). The granodiorites and tonalites that host the Veikkola granites are synorogenic rocks that vary from non-foliated to pervasively foliated and folded ones; generally they are more complexly deformed than the lateorogenic Veikkola granites. To the south the Veikkola granites are surrounded by foliated, garnet-bearing granites with schlieren-type biotite-rich xenoliths of older rocks. These granites have been considered lateorogenic in published maps (e.g. Korsman et al., 1997). We do not know their age but, as the Veikkola granites crosscut the foliation seen in these granites, we excluded them from the Veikkola granite group.

The large host rock raft at the southern margin of the granite area consists of fine-grained, layered mica schist crosscut by medium-grained, foliated synorogenic tonalite. These rocks are crosscut by mafic dikes that in turn are crosscut by the Veikkola granites.

The supracrustal rocks northwest and north of the Veikkola area constitute the West Uusimaa Complex (WUC) characterized by granulite facies assemblages (Fig. 1). Parras (1958) originally included the garnetcordierite paragneisses adjacent to the Veikkola granite area into the WUC but the "orthopyroxene-in" line defined by Schreurs and Westra (1986) constrain the granulite facies rocks into a smaller area than the one defined by Parras (1958).

\subsection{Bodom granite and diabase dikes}

The Bodom rapakivi intrusion (Fig. 2) is of $\sim 1.64 \mathrm{Ga}$ age (Kosunen, 1999). A swarm of WNW trending diabase dikes are seen on aeromagnetic map as straight positive anomalies, and on a few outcrops as steeply dipping dikes $20-100 \mathrm{~cm}$ in width. The age of these dikes is not known but their location and orientation suggest that they are part of the rapakivi event.

\subsection{Veikkola granites}

Although the Veikkola granites contain few schlierenlike remnants of partially fused host rock these are not abundant as in typical lateorogenic granites. Even-grained, porphyritic and layered granites could be discerned in the Veikkola area. The granites are fairly felsic, with biotite (around $5 \%$ ) and garnet as mafic minerals. Felsic layers and veins contain garnet as the (almost) only mafic mineral. The latest, sharply crosscutting granite dikes do not contain garnet. We discerned four granite types in the Veikkola area. In the order of decreasing age, based on field studies, these are the Nuuksio granite (NG), the Haapajärvi granite (HG), the Evitskog granite (EG), and the Kylmälä granite (KG; Fig. 2). As can be seen from Fig. 2, the locus of magmatism has moved slightly westwards with time.

\subsection{Nuuksio granite}

The Nuuksio granite is the most widespread granite type and covers the northern and eastern part of the granite area. The granite is layered with medium- to coarse-grained, felsic, garnet-rich layers occurring in a slightly more mafic, medium-grained biotite granite (Fig. 3a). The width of the felsic layers is $2-20 \mathrm{~cm}$. Although the layering is typically distinct, the rock is not strongly deformed: the felsic minerals are not flattened, microfractured or recrystallized into ribbons, and undulatory extinction of quartz is the only ex- 
pression of deformation. The boundaries of the layers are usually gradational (Fig. 3b); pegmatitic veins with sharp upper boundaries are also found. In places felsic veins form a net-veined pattern, and few garnet-bearing veins are at high angles to the layering. In the felsic layers garnet typically occurs as a chain of grains close to the boundaries of the layers. The grains are anhedral to subhedral, range in size from $2 \mathrm{~mm}$ up to $20 \mathrm{~mm}$, and are commonly partly replaced by biotite (relics of garnet occur in the center of biotite aggregates). In places aggregates of small subhedral garnet occur in small felsic veinlets. Some aggregates are surrounded by biotite-free quartz-feldspar zones (Fig. 3c). The garnet content of the granite varies; in places it is absent. The grain-size of garnet is slightly smaller in the host granite than in the felsic layers, and the garnet grains are generally anhedral.

The dominant orientation that is seen as layering in the Nuuksio granite continues across the boundaries into the host sedimentary rocks to the northwest: layer-parallel garnet-bearing granitic dikes are found in the garnet-cordierite paragneiss.

The Nuuksio granite has been dated at $1852 \pm 3$ Ma by the U-Pb method on monazite and at 1853 \pm 7 Ma on zircon (samples A1695 and A1733, respectively in Kurhila et al., 2005).

\subsubsection{Haapajärvi granite}

The Haapajärvi granite is located in the center of the Veikkola area (Fig 2). The present study was initiated because new datings had showed a zircon age of $1829 \pm 7 \mathrm{Ma}$ and a monazite age of $1825 \pm 3 \mathrm{Ma}$ (sample A1718 in Kurhila et al., 2005) that differ by $\sim 25 \mathrm{Ma}$ from the age of the Nuuksio granite. The Haapajärvi granite is more homogeneous than the Nuuksio granite. It also contains garnet but not as much as the Nuuksio granite. The size of the anhedral garnet grains is $2-10 \mathrm{~mm}$. There are felsic, garnet-bearing veins in the granite and the texture varies from faintly layered to faintly net-veined (Fig. 3d). The youngest veins are pegmatitic. On some roadcuts along Highway 1 the Haapajärvi granite crosscuts the Nuuksio granite but in general it is difficult to discern these two granite types from each other.

\subsubsection{Evitskog granite}

The Evitskog granite is a porphyritic biotite granite with K-feldspar phenocrysts up to $5 \mathrm{~cm}$ long within a medium-grained matrix. Generally the phenocrysts are abundant but unevenly distributed. The Evitskog granite locally contains anhedral garnet, $5-20 \mathrm{~mm}$ in diameter, or biotite aggregates cored by relic garnet. The matrix is weakly foliated to non-foliated but in places the elongate phenocrysts express a distinct foliation which likely is magmatic. Rare biotite-rich schlieren are aligned parallel to the magmatic foliation. The Evitskog granite has been dated at $1824 \pm 5$ Ma by zircon and at $1822 \pm 3$ Ma by monazite (sample A1694 in Kurhila et al., 2005).

\subsubsection{Kylmälä granite}

The Kylmälä granite is even-grained and slightly foliated to non-foliated biotite-muscovite granite. The granite contains anhedral garnet $5-8 \mathrm{~mm}$ in diameter, in lesser abundance than the Nuuksio and Haapajärvi granites. Where observable in the field the boundary between the Evitskog and Kylmälä granites is gradational, with alternating layers of porphyritic and even-grained granite. However, at one location the Kylmälä granite sharply crosscuts the magmatic foliation in the Evitskog granite. The Kylmälä granite contains ghost-like xenoliths of foliated (synorogenic?) granite, pegmatitic veins with gradational contacts as well as sharply crosscutting granitic dikes that contain anhedral garnet. In the eastern part of the Kylmälä granite there is a fine-grained granite area containing anhedral garnet $5 \mathrm{~mm}$ in diameter; this is probably the latest granite phase except for the crosscutting granitic dikes that range from mediumgrained to pegmatitic. 

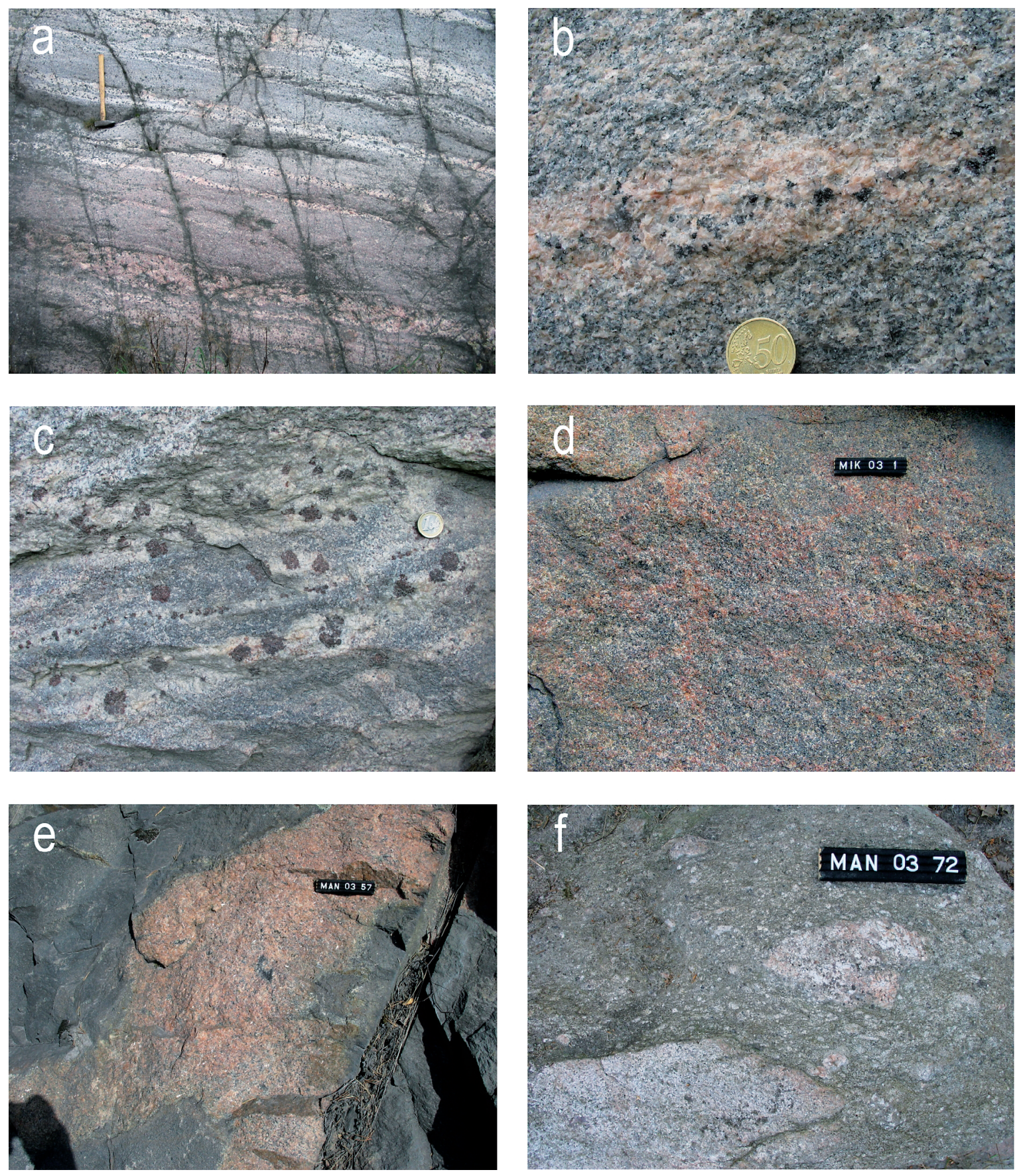

Fig. 3. Rock types in the Veikkola area (see Fig. 2 for locations). a) Layered Nuuksio granite. Length of hammer $65 \mathrm{~cm}$. b) Gradational boundaries between felsic layer and host Nuuksio granite. The dark spots in the felsic layer are garnet. Diameter of coin $2.3 \mathrm{~cm}$. c) Aggregates of subhedral garnet in felsic veinlets of the Nuuksio granite. Diameter of coin $2.3 \mathrm{~cm}$. d) Faint net-veined pattern in the Haapajärvi granite. Length of code bar $12 \mathrm{~cm}$. e) Vein of the Haapajärvi granite in enderbite. Note the change from sharp to gradational boundary. f) Granite xenoliths in foliated enderbite within the Kylmälä granite. 


\subsection{Enderbite}

Outcrops of fine-grained, pyroxene-bearing rock are found in the central part of the Veikkola granite area (Fig. 2). The rock is of intermediate composition, consisting of plagioclase ( $43-59 \%)$, quartz $(10-23 \%)$, biotite $(9-17 \%)$ and pyroxene $(14-22 \%$, clinopyroxene in excess of orthopyroxene) as main constituents. Small $(2-4 \mathrm{~mm})$, anhedral to subhedral plagioclase phenocrysts are common, and biotite laths show a faint to conspicuous foliation. The tonalitic composition and orthopyroxene-bearing mineralogy allow the rock to be called enderbite, although the plagioclase phenocrysts suggest a subvolcanic rather than truly plutonic rock. The granoblastic texture and anhedral pyroxene grains imply that the texture is metamorphic. Assessment of origin (e.g. indications of magma mixing) is hampered by metamorphism, e.g. the phenocrysts are unzoned.

The enderbite has injected the Nuuksio and Haapajärvi granites as subhorizontal sills and dikes. In places the Haapajärvi granite has injected the enderbite as veins, probably as an expression of back-veining. Contacts are from sharp to gradational within $10-20 \mathrm{~cm}$ so that the granite becomes more mafic towards the contact (Fig. 3e). On the basis of these evidence we consider that the Haapajärvi granite and the enderbite are coeval.

Enderbite occupies also a large area in the Kylmälä granite (Fig. 2). Here, the rock differs from the other enderbite occurrences in being coarser, varying in composition from tonalite to granodiorite, and containing in places small granite xenoliths (Fig. 3f). In lack of contact evidence it is unclear whether the enderbite is intrusive to or a xenolith within the Kylmälä granite.

\section{Structures}

The planar features of the Veikkola granites define a bowl-shaped structure with horizontal foliation in the center (Fig. 4a). A notable thing is that foliation is rarely pervasive (usually layering or preferred ori- entation of phenocrysts) and that the oldest Nuuksio granite has only a weak fabric. The foliation is weakest in the Kylmälä granite in which it is localized.

The local structural sequence can be seen in the host rock raft in the southern part of the Veikkola granite area (Fig. 4b). The compositional layering in the mica schist exhibits recumbent folding of $S_{A}$ foliation $\left(\mathrm{F}_{\mathrm{B}}\right.$; Fig. 5a). Recumbent $\mathrm{F}_{\mathrm{B}}$ folds, subhorizontal $S_{B}$ penetrative axial-planar foliation, and related gently northeast plunging $L_{B}$ lineations along fold axes are visible in the mica schist, in the crosscutting synorogenic tonalite, and in a mafic dyke that crosscuts the tonalite (Fig. 5b). The compositional layering in the mica schist exhibits also boudinage, with $\mathrm{L}_{B}$ parallel to boudin necks. The $\mathrm{S}_{B}$ axial plane foliation has been openly folded $\left(\mathrm{F}_{\mathrm{C}}\right)$ along an ENEWSW trending subvertical axial plane and subhorizontal axis (Figs. 4b and 4c). Dikes from the Kylmälä granite have intruded along $S_{B}$ planes but in detail they sharply crosscut $F_{B}$ structures (Fig. 5c).

The foliation in the Veikkola granites may be correlated with $S_{B}$ in the host rock raft. Direct evidence for open $F_{C}$ folding of the layering $\left(S_{B}\right)$ in the Nuuksio granite is seen at roadcuts along Highway 1 whereas Fc folding of the Haapajärvi and Evitskog granites becomes evident from the varying dip angles of the ENE-WSW trending $S_{B}$ foliation. Open to tight, upright $F_{D}$ folds with approximately N-S trending axial planes and gently north and south plunging fold axes are found in the host rock raft and in the Evitskog granite (Figs. 4a, 4b and 5d). This event has deformed older structures without development of a new axial-planar foliation. The zonal foliation in the Kylmälä granite with low-angle dips (Fig. 4a) may be associated with $\mathrm{F}_{\mathrm{B}}$ rather than upright $\mathrm{F}_{\mathrm{D}}$ folding but the crosscutting dikes show that the Kylmälä granite was emplaced at the end of $D_{B}$ deformation.

On the basis of the observations above, the synorogenic granodiorites surrounding the Veikkola granites were emplaced before $\mathrm{D}_{\mathrm{B}}$ deformation whereas the Veikkola granites were emplaced before or during $\mathrm{D}_{\mathrm{B}}$, before contractional $\mathrm{D}_{\mathrm{C}}$ deformation. 


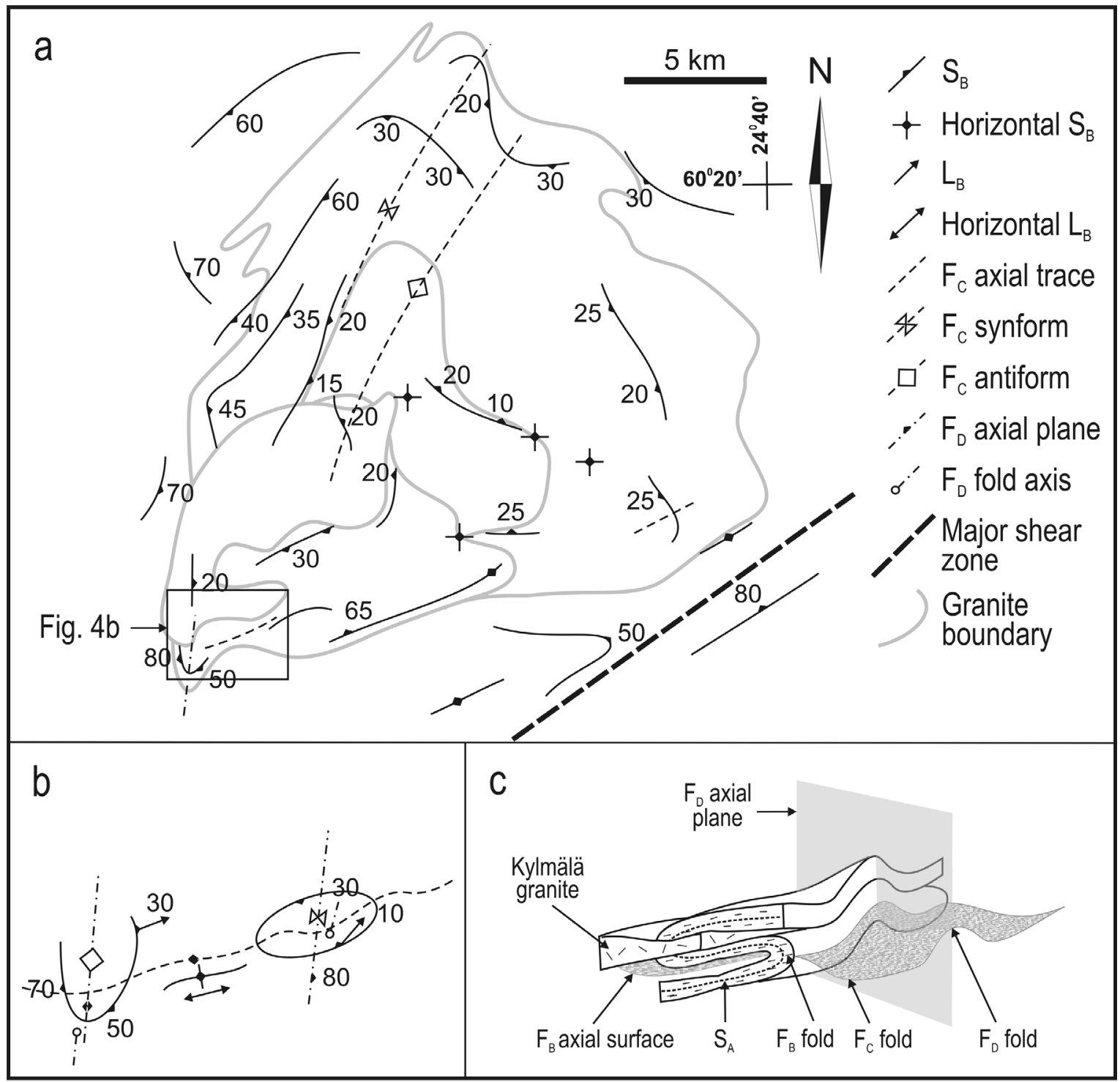

Fig. 4. Structural interpretation of the Veikkola area. a) General foliation trends in and around the Veikkola granites. b) Structures in the host rocks that occur as a raft within the Evitskog granite. c) Schematic picture of the structures in the area of Fig. 4b, looking northeast.

\section{Geochemistry}

\section{I.Analytical methods}

The samples of the Veikkola granites, 29 in total, and three samples of enderbite were analyzed in the Chemical Laboratory of the GTK (Geological Survey of Finland). The samples of the granites and enderbite, weighing between 4 and $7 \mathrm{~kg}$, were collected with hammer. The samples of the felsic layers and veins were collected with hammer and mini-drill machine; the weight of the samples was between 0.5 and $5 \mathrm{~kg}$. The samples were jaw crushed, and splits were pulverized in a tungsten-carbide bowl for XRF analysis, and in carbon steel bowl for ICP-MS. Major elements and $\mathrm{Rb}, \mathrm{Sr}, \mathrm{Zr}$, and Ba were determined by XRF, and $\mathrm{Nb}$, $\mathrm{Y}, \mathrm{Th}, \mathrm{U}$, and rare earth elements by ICP-MS. 

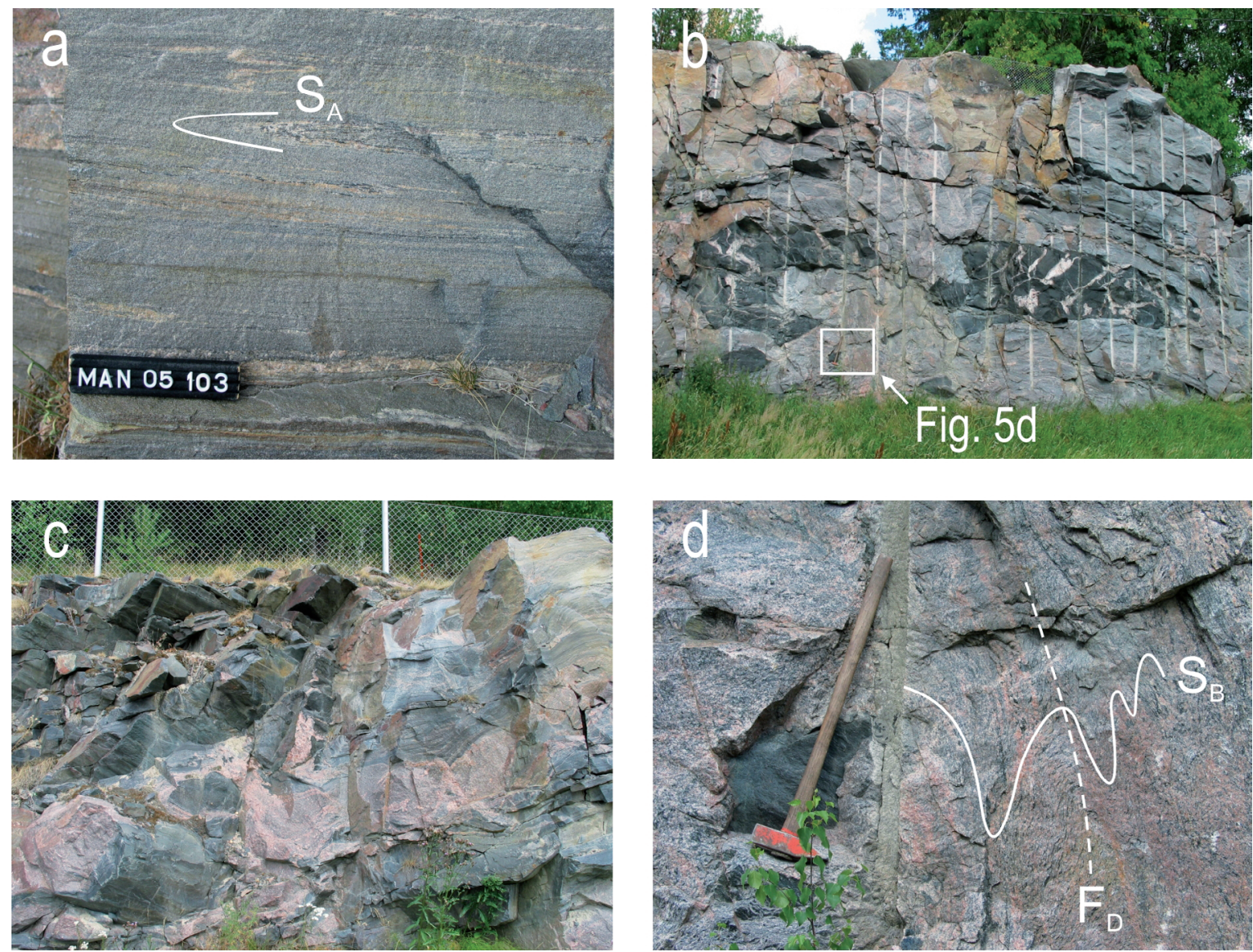

Fig. 5. Structures in roadcuts, looking north (see Fig. 2 for locations). a) Recumbently $F_{B}$ folded $S_{A}$ foliation in mica schist, showing subhorizontal $S_{B}$ as the dominant foliation. Length of code bar $12 \mathrm{~cm}$. b) Recumbently $F_{B}$ folded synorogenic tonalite and mafic dike, with subhorizontal $S_{B}$. Width of view $12 \mathrm{~m}$. c) Dike from the Kylmälä granite injected parallel to $S_{B}$ in mica schist. Note conspicuous $L_{B}$ lineation in mica schist. Width of view $6 \mathrm{~m}$. d) Close-up of Fig. $5 a$ showing upright $F_{D}$ folding of penetrative $S_{B}$ foliation in synorogenic tonalite. Length of hammer $65 \mathrm{~cm}$.

\subsection{Granites}

The geochemistry of the granites and the felsic layers and veins has been treated separately (Table 1, Figs. 6 and 7). The geochemistry of the granites is compared with that of a lateorogenic granite in the Nagu area and an A-type granite at Karjaa (Fig. 1, Table 1). The Nagu granite is a porphyritic one with felsic veins that in places contain abundant garnet (Stålfors \& Ehlers, 2006). The Karjaa granite crosscuts lateorogenic granites but its age $(1826 \pm 11 \mathrm{Ma}$; Jurvanen et al., 2005) is comparable to the Haapajärvi and Evitskog granites.
In general, the Veikkola granites have a large variation in their major and minor element contents considering the tight $\mathrm{SiO}_{2}$ range (70.9 - 75.5 wt.\%; Fig. 6). The different granite types in the Veikkola area are generally similar but the Nuuksio granite has slightly higher $\mathrm{Ca}, \mathrm{Na}$ and $\mathrm{Sr}$, and lower $\mathrm{K}, \mathrm{Rb}$ and $\mathrm{Fe} / \mathrm{Mg}$ at a given $\mathrm{SiO}_{2}$ value than the other granite types. All granite types are leucocratic $\left(\mathrm{FeO}_{\text {tot }}+\right.$ $\mathrm{MgO}+\mathrm{TiO}_{2}<3 \mathrm{wt} . \%$ ) and marginally peraluminous (A/CNK 1.1; Table 1). The felsic layers and veins associated with the Nuuksio and Haapajärvi granites show a wider variation in composition than the host granites. The felsic layers and veins are higher in $\mathrm{Mn}$, 
Table I. Chemical composition of the granites in the Veikkola area. Arithmetic mean compositions of the late orogenic Nagu and Karjaa granites are shown for comparison.

\begin{tabular}{|c|c|c|c|c|c|c|c|c|c|c|}
\hline Group & $\begin{array}{l}\text { Nuuksio } \\
\text { granite }\end{array}$ & & & & & & & & & \\
\hline Sample & NG1 & NG2 & NG3 & NG4 & NG5 & NG6 & NG7 & NG8 & NG9 & NG10 \\
\hline $\mathrm{SiO}_{2}$ (wt.\%) & 72.7 & 70.9 & 72.2 & 73.4 & 74.3 & 74.1 & 75.2 & 71.4 & 72.7 & 72.3 \\
\hline $\mathrm{TiO}_{2}$ & 0.25 & 0.30 & 0.30 & 0.22 & 0.26 & 0.23 & 0.16 & 0.36 & 0.22 & 0.25 \\
\hline $\mathrm{Al}_{2} \mathrm{O}_{3}$ & 14.4 & 15.0 & 14.6 & 13.8 & 13.9 & 13.9 & 13.6 & 15.1 & 14.0 & 14.0 \\
\hline $\mathrm{FeO}_{\text {tor }}$ & 1.39 & 1.85 & 2.08 & 1.15 & 1.31 & 1.54 & 0.82 & 2.16 & 1.19 & 1.85 \\
\hline $\mathrm{MnO}$ & 0.02 & 0.01 & 0.02 & 0.01 & 0.01 & 0.01 & 0.01 & 0.02 & 0.01 & 0.02 \\
\hline $\mathrm{MgO}$ & 0.45 & 0.73 & 0.52 & 0.41 & 0.34 & 0.34 & 0.24 & 0.79 & 0.38 & 0.50 \\
\hline $\mathrm{CaO}$ & 1.12 & 2.43 & 1.67 & 1.13 & 1.33 & 1.16 & 1.01 & 2.32 & 1.16 & 1.37 \\
\hline $\mathrm{Na}_{2} \mathrm{O}$ & 3.02 & 3.75 & 3.39 & 2.92 & 3.49 & 3.37 & 2.97 & 3.72 & 3.46 & 3.29 \\
\hline $\mathrm{K}_{2} \mathrm{O}$ & 5.46 & 3.30 & 4.57 & 5.37 & 4.52 & 4.75 & 5.55 & 3.46 & 4.71 & 4.80 \\
\hline $\mathrm{P}_{2} \mathrm{O}_{5}$ & 0.06 & 0.09 & 0.04 & 0.04 & 0.04 & 0.05 & 0.05 & 0.16 & 0.04 & 0.11 \\
\hline $\mathrm{Ba}(\mathrm{ppm})$ & 628 & 522 & 638 & 600 & 424 & 495 & 496 & 697 & 442 & 658 \\
\hline $\mathrm{Rb}$ & 163 & 105 & 132 & 138 & 196 & 190 & 163 & 112 & 127 & 150 \\
\hline $\mathrm{Sr}$ & 165 & 310 & 160 & 169 & 108 & 137 & 125 & 264 & 103 & 184 \\
\hline $\mathrm{Zr}$ & 199 & 142 & 193 & 134 & 132 & 167 & 93 & 181 & 136 & 186 \\
\hline $\mathrm{Nb}$ & 12.4 & 12.2 & 14.0 & 9.2 & 23.9 & 17.4 & 5.9 & 11.6 & 7.6 & 9.0 \\
\hline Y & 15.3 & 7.9 & 25.3 & 5.97 & 5.89 & 12.4 & 4.55 & 11.7 & 9.62 & 15.3 \\
\hline Th & 38.7 & 21.2 & 35.8 & 24.6 & 26.9 & 32.1 & 15.2 & 13.9 & 21.6 & 30.1 \\
\hline $\mathrm{U}$ & 3.00 & 1.16 & 2.24 & 1.90 & 5.02 & 3.52 & 1.43 & 1.73 & 2.36 & 3.86 \\
\hline $\mathrm{La}$ & 67.3 & 49.2 & 63.4 & 47.5 & 46.1 & 50.4 & 31.0 & 34.2 & 46.4 & 53.9 \\
\hline $\mathrm{Ce}$ & 132 & 94 & 131 & 91 & 94 & 104 & 64 & 67 & 89 & 105 \\
\hline $\operatorname{Pr}$ & 14.9 & 10.4 & 14.4 & 10.7 & 10.0 & 11.1 & 6.9 & 7.2 & 9.9 & 11.6 \\
\hline $\mathrm{Nd}$ & 49.5 & 36.3 & 52.5 & 37.6 & 35.6 & 40.2 & 24.1 & 25.2 & 35 & 41.9 \\
\hline $\mathrm{Sm}$ & 9.43 & 6.43 & 10.7 & 7.23 & 6.54 & 7.50 & 4.31 & 5.36 & 6.17 & 7.67 \\
\hline $\mathrm{Eu}$ & 0.64 & 0.70 & 0.65 & 0.66 & 0.53 & 0.58 & 0.51 & 0.87 & 0.56 & 0.7 \\
\hline Gd & 7.67 & 5.29 & 9.27 & 6.01 & 5.55 & 6.74 & 3.43 & 4.84 & 5.28 & 7.17 \\
\hline $\mathrm{Tb}$ & 0.99 & 0.55 & 1.11 & 0.67 & 0.64 & 0.79 & 0.39 & 0.68 & 0.67 & 1.01 \\
\hline Dy & 3.74 & 2.19 & 4.92 & 1.97 & 1.84 & 3.17 & 1.49 & 3.09 & 2.32 & 3.92 \\
\hline Ho & 0.53 & 0.31 & 0.81 & 0.22 & 0.21 & 0.39 & 0.15 & 0.39 & 0.32 & 0.53 \\
\hline Er & 1.20 & 0.56 & 2.42 & 0.39 & 0.31 & 0.90 & 0.25 & 0.91 & 0.77 & 1.33 \\
\hline $\mathrm{Tm}$ & 0.13 & b.d. & 0.32 & b.d. & b.d. & 0.13 & b.d. & 0.11 & b.d. & 0.16 \\
\hline $\mathrm{Yb}$ & 0.77 & 0.22 & 1.82 & 0.32 & 0.36 & 0.75 & 0.27 & 0.61 & 0.62 & 1.2 \\
\hline $\mathrm{Lu}$ & b.d. & b.d. & 0.26 & b.d. & b.d. & 0.12 & b.d. & b.d. & b.d. & 0.19 \\
\hline $\mathrm{A} / \mathrm{CNK}$ & 1.11 & 1.06 & 1.08 & 1.09 & 1.07 & 1.09 & 1.07 & 1.07 & 1.09 & 1.07 \\
\hline $\mathrm{FeO} / \mathrm{MgO}$ & 3.05 & 2.55 & 4.00 & 2.80 & 3.86 & 4.52 & 3.40 & 2.74 & 3.13 & 3.70 \\
\hline$(\mathrm{La} / \mathrm{Yb})_{\mathrm{N}}$ & 58.7 & 150 & 23.5 & 100 & 86.3 & 45.3 & 77.4 & 37.8 & 50.5 & 30.3 \\
\hline $\mathrm{Eu} / \mathrm{Eu}^{*}$ & 0.22 & 0.36 & 0.20 & 0.30 & 0.26 & 0.24 & 0.39 & 0.51 & 0.29 & 0.28 \\
\hline
\end{tabular}


Table I. (cont.) Chemical composition of the granites in the Veikkola area. Arithmetic mean compositions of the late orogenic Nagu and Karjaa granites are shown for comparison.

\begin{tabular}{|c|c|c|c|c|c|c|c|c|c|c|c|}
\hline Group & $\begin{array}{l}\text { felsic } \\
\text { layer/vein }\end{array}$ & & & & & & $\begin{array}{l}\text { Haapajärvi } \\
\text { granite }\end{array}$ & & & felsic vein & \\
\hline Sample & NG3/f1 & NG3/f2 & NG5/f & NG6/f & NG7/f & NG8/f & HG1 & HG2 & HG3 & HG2/f1 & $\mathrm{HG} 2 / \mathrm{f} 2$ \\
\hline $\mathrm{SiO}_{2}$ (wt.\%) & 67.4 & 74.1 & 75.8 & 73.8 & 73.8 & 67.5 & 73.2 & 74.5 & 74.6 & 73.8 & 73.6 \\
\hline $\mathrm{TiO}_{2}$ & 0.05 & 0.02 & 0.04 & 0.03 & 0.01 & 0.05 & 0.21 & 0.21 & 0.22 & 0.10 & 0.06 \\
\hline $\mathrm{Al}_{2} \mathrm{O}_{3}$ & 16.1 & 13.3 & 13.5 & 13.9 & 14.4 & 17.5 & 14.1 & 13.6 & 13.5 & 13.9 & 14.8 \\
\hline $\mathrm{FeO}_{\text {tot }}$ & 4.56 & 2.48 & 0.92 & 1.74 & 1.31 & 1.90 & 1.58 & 1.55 & 1.31 & 1.98 & 2.02 \\
\hline $\mathrm{MnO}$ & 0.14 & 0.07 & 0.03 & 0.04 & 0.03 & 0.08 & 0.04 & 0.02 & 0.01 & 0.07 & 0.06 \\
\hline $\mathrm{MgO}$ & 0.42 & 0.23 & 0.09 & 0.16 & 0.14 & 0.30 & 0.31 & 0.21 & 0.20 & 0.13 & 0.27 \\
\hline $\mathrm{CaO}$ & 1.15 & 0.86 & 0.77 & 0.54 & 1.27 & 1.55 & 0.69 & 0.79 & 0.72 & 0.75 & 2.92 \\
\hline $\mathrm{Na}_{2} \mathrm{O}$ & 3.08 & 2.37 & 3.11 & 3.03 & 3.06 & 3.75 & 2.78 & 3.03 & 3.00 & 3.09 & 4.16 \\
\hline $\mathrm{K}_{2} \mathrm{O}$ & 6.14 & 5.85 & 5.33 & 6.19 & 5.45 & 6.56 & 6.35 & 5.60 & 5.84 & 5.59 & 1.25 \\
\hline $\mathrm{P}_{2} \mathrm{O}_{5}$ & 0.07 & 0.04 & 0.05 & 0.07 & 0.05 & 0.16 & 0.06 & 0.05 & 0.05 & 0.06 & 0.10 \\
\hline $\mathrm{Ba}(\mathrm{ppm})$ & 869 & 750 & 491 & 635 & 404 & 1424 & 437 & 389 & 398 & 372 & 67 \\
\hline $\mathrm{Rb}$ & 153 & 131 & 179 & 229 & 139 & 157 & 238 & 262 & 267 & 233 & 24 \\
\hline $\mathrm{Sr}$ & 163 & 139 & 113 & 133 & 126 & 326 & 78 & 55 & 60 & 55 & 76 \\
\hline $\mathrm{Zr}$ & 174 & 97 & 100 & 103 & 173 & 44 & 183 & 177 & 173 & 155 & 507 \\
\hline $\mathrm{Nb}$ & 1.9 & 0.7 & 2.2 & 2.6 & 0.3 & 1.3 & 15.3 & 16.9 & 17.3 & 10.3 & 2.1 \\
\hline Y & 146 & 82.9 & 14.6 & 39.0 & 34.6 & 39.9 & 38.0 & 22.3 & 12.2 & 65.3 & 59.3 \\
\hline Th & 87.7 & 27.5 & 16.2 & 36.5 & 40.7 & 111 & 41.1 & 31.2 & 33.9 & 32.5 & 136.0 \\
\hline $\mathrm{U}$ & 4.07 & 1.50 & 3.80 & 4.59 & 2.30 & 4.81 & 3.95 & 3.54 & 3.70 & 3.66 & 3.30 \\
\hline $\mathrm{La}$ & 152 & 59.3 & 27.2 & 52.2 & 87.0 & 188 & 73.6 & 62.9 & 70.9 & 60.2 & 366 \\
\hline $\mathrm{Ce}$ & 322 & 120 & 56 & 108 & 184 & 408 & 154 & 132 & 130 & 127 & 762 \\
\hline $\operatorname{Pr}$ & 36.3 & 12.8 & 6.1 & 11.7 & 20.2 & 47.1 & 18.1 & 14.9 & 13.6 & 14.3 & 87.7 \\
\hline $\mathrm{Nd}$ & 133 & 46.8 & 21.7 & 41.7 & 71.2 & 177 & 60.9 & 54.2 & 49.1 & 52.5 & 318 \\
\hline $\mathrm{Sm}$ & 24.5 & 8.00 & 4.17 & 8.31 & 11.7 & 34.8 & 11.8 & 9.68 & 10.1 & 8.94 & 44.9 \\
\hline $\mathrm{Eu}$ & 0.76 & 0.66 & 0.43 & 0.63 & 0.61 & 1.30 & 0.52 & 0.45 & 0.56 & 0.42 & 0.60 \\
\hline Gd & 22.0 & 7.18 & 3.43 & 7.73 & 9.11 & 27.1 & 9.68 & 8.02 & 8.64 & 7.92 & 30.8 \\
\hline $\mathrm{Tb}$ & 3.26 & 1.34 & 0.52 & 1.13 & 1.15 & 2.84 & 1.32 & 0.99 & 0.8 & 1.33 & 3.22 \\
\hline Dy & 21.7 & 11.0 & 2.82 & 6.02 & 6.17 & 9.61 & 6.80 & 4.48 & 3.5 & 9.19 & 11.7 \\
\hline Ho & 5.17 & 2.97 & 0.50 & 1.30 & 1.22 & 1.57 & 1.27 & 0.74 & 0.45 & 2.14 & 2.18 \\
\hline $\mathrm{Er}$ & 16.6 & 9.94 & 1.20 & 3.91 & 3.25 & 3.95 & 3.45 & 1.93 & 0.65 & 6.83 & 6.14 \\
\hline $\mathrm{Tm}$ & 2.44 & 1.43 & 0.17 & 0.57 & 0.44 & 0.47 & 0.54 & 0.25 & b.d. & 0.99 & 0.99 \\
\hline $\mathrm{Yb}$ & 14.8 & 8.43 & 1.28 & 3.56 & 2.65 & 2.93 & 3.36 & 1.71 & 0.56 & 6.45 & 6.59 \\
\hline $\mathrm{Lu}$ & 1.88 & 1.09 & 0.19 & 0.50 & 0.41 & 0.39 & 0.45 & 0.20 & b.d. & 0.85 & 0.98 \\
\hline $\mathrm{A} / \mathrm{CNK}$ & 1.17 & 1.13 & 1.10 & 1.10 & 1.09 & 1.09 & 1.11 & 1.09 & 1.07 & 1.11 & 1.10 \\
\hline $\mathrm{FeO} / \mathrm{MgO}$ & 10.9 & 10.8 & 10.2 & 10.9 & 9.33 & 6.33 & 5.19 & 7.37 & 6.53 & 15.19 & 7.49 \\
\hline$(\mathrm{La} / \mathrm{Yb})_{\mathrm{N}}$ & 6.9 & 4.74 & 14.3 & 9.89 & 22.1 & 43.3 & 14.8 & 24.8 & 85.4 & 6.29 & 37.4 \\
\hline $\mathrm{Eu} / \mathrm{Eu}^{*}$ & 0.10 & 0.26 & 0.34 & 0.24 & 0.17 & 0.12 & 0.14 & 0.15 & 0.18 & 0.15 & 0.05 \\
\hline
\end{tabular}


Table I. (cont.) Chemical composition of the granites in the Veikkola area. Arithmetic mean compositions of the late orogenic Nagu and Karjaa granites are shown for comparison.

\begin{tabular}{|c|c|c|c|c|c|c|c|c|c|c|c|c|c|}
\hline Group & $\begin{array}{l}\text { Evitskog } \\
\text { granite }\end{array}$ & & & & $\begin{array}{l}\text { Kylmä } \\
\text { granite }\end{array}$ & & & & $\begin{array}{l}\text { Veikkola } \\
\text { granites }\end{array}$ & $\begin{array}{l}\text { felsic } \\
\text { layers }\end{array}$ & $\begin{array}{l}\text { Nagu } \\
\text { granite }\end{array}$ & $\begin{array}{l}\text { felsic } \\
\text { layers }\end{array}$ & $\begin{array}{l}\text { Karjaa } \\
\text { granite }\end{array}$ \\
\hline Sample & EG1 & EG2 & EG3 & EG4 & KG1 & KG2 & KG3 & KG4 & & & & & \\
\hline & & & & & & & & & $(\mathrm{N}=21)$ & $(\mathrm{N}=8)$ & $(\mathrm{N}=15)$ & $(\mathrm{N}=6)$ & $(\mathrm{N}=7)$ \\
\hline $\mathrm{SiO}_{2}$ (wt.\%) & 72.8 & 74.1 & 74.4 & 74.3 & 73.0 & 73.9 & 75.5 & 73.9 & 73.5 & 72.5 & 73.6 & 75.82 & 67.4 \\
\hline $\mathrm{TiO}_{2}$ & 0.22 & 0.21 & 0.19 & 0.20 & 0.14 & 0.29 & 0.17 & 0.24 & 0.23 & 0.04 & 0.21 & 0.05 & 0.81 \\
\hline $\mathrm{Al}_{2} \mathrm{O}_{3}$ & 13.9 & 13.3 & 13.4 & 13.5 & 14.5 & 13.6 & 13.3 & 13.7 & 13.9 & 14.7 & 13.7 & 13.08 & 14.6 \\
\hline $\mathrm{FeO}_{\text {tot }}$ & 1.66 & 2.21 & 1.73 & 1.63 & 1.62 & 2.06 & 1.33 & 1.69 & 1.61 & 2.11 & 1.82 & 0.78 & 4.28 \\
\hline $\mathrm{MnO}$ & 0.02 & 0.02 & 0.02 & 0.02 & 0.04 & 0.03 & 0.02 & 0.01 & 0.02 & 0.07 & 0.02 & 0.02 & 0.04 \\
\hline $\mathrm{MgO}$ & 0.34 & 0.28 & 0.24 & 0.25 & 0.35 & 0.38 & 0.24 & 0.31 & 0.37 & 0.22 & 0.37 & 0.12 & 0.93 \\
\hline $\mathrm{CaO}$ & 0.76 & 0.71 & 0.78 & 0.93 & 1.36 & 0.75 & 0.93 & 0.96 & 1.15 & 1.23 & 0.88 & 0.73 & 1.91 \\
\hline $\mathrm{K}_{2} \mathrm{O}$ & 5.97 & 5.79 & 5.83 & 5.58 & 5.00 & 5.65 & 5.03 & 5.56 & 5.18 & 5.29 & 5.93 & 5.97 & 5.23 \\
\hline $\mathrm{P}_{2} \mathrm{O}_{5}$ & 0.07 & 0.07 & 0.07 & 0.05 & 0.07 & 0.06 & 0.05 & 0.08 & 0.06 & 0.07 & 0.07 & 0.07 & 0.22 \\
\hline $\mathrm{Ba}(\mathrm{ppm})$ & 386 & 251 & 342 & 320 & 606 & 515 & 338 & 340 & 472 & 627 & 372 & 342 & 1557 \\
\hline $\mathrm{Rb}$ & 341 & 304 & 290 & 268 & 148 & 210 & 214 & 247 & 203 & 156 & 201 & 196 & 176 \\
\hline $\mathrm{Sr}$ & 74 & 53 & 65 & 62 & 176 & 91 & 75 & 73 & 123 & 141 & 77.5 & 74.3 & 170 \\
\hline $\mathrm{Zr}$ & 187 & 216 & 157 & 163 & 125 & 221 & 92 & 164 & 163 & 169 & 175 & 57.5 & 703 \\
\hline $\mathrm{Nb}$ & 24.9 & 29.4 & 20.6 & 19.8 & 6.6 & 15.0 & 11.9 & 20.7 & 18.8 & 12.0 & 10.1 & 2.17 & 23.3 \\
\hline Y & 27.6 & 36.3 & 28.3 & 18.1 & 19.6 & 22.1 & 16.9 & 15.8 & 20.6 & 57.6 & 21.9 & 10.7 & 31.4 \\
\hline Th & 46.3 & 49.0 & 30.3 & 27.8 & 22.4 & 46.9 & 34.9 & 31.7 & 31.2 & 61.0 & 39.2 & 5.70 & 23.2 \\
\hline $\mathrm{U}$ & 10.2 & 8.48 & 10.0 & 3.10 & 2.80 & 3.69 & 3.04 & 3.17 & 3.90 & 3.50 & 3.39 & 1.55 & \\
\hline $\mathrm{Ce}$ & 141 & 206 & 107 & 102 & 77.3 & 185 & 143 & 126 & 118 & 261 & 134 & 22.5 & 267 \\
\hline $\operatorname{Pr}$ & 16.7 & 23.0 & 12.1 & 11.8 & 8.53 & 20.5 & 16.0 & 14.2 & 13.2 & 29.5 & 16.1 & 2.41 & 28.5 \\
\hline $\mathrm{Nd}$ & 60.0 & 83.3 & 44.8 & 44.6 & 30.9 & 76.7 & 62.2 & 53.6 & 47.5 & 108 & 59.4 & 8.82 & 102 \\
\hline $\mathrm{Sm}$ & 12.5 & 15.9 & 8.22 & 7.97 & 5.47 & 13.2 & 10.9 & 10.1 & 8.91 & 18.2 & 10.5 & 1.63 & 15.8 \\
\hline $\mathrm{Eu}$ & 0.52 & 0.40 & 0.46 & 0.40 & 0.73 & 0.66 & 0.49 & 0.51 & 0.58 & 0.68 & 0.57 & 0.48 & 2.11 \\
\hline $\mathrm{Gd}$ & 10.7 & 13.0 & 7.89 & 7.42 & 5.47 & 11.2 & 9.40 & 8.80 & 7.69 & 14.4 & 7.96 & 1.47 & 13.1 \\
\hline $\mathrm{Tb}$ & 1.44 & 1.75 & 1.03 & 0.95 & 0.74 & 1.30 & 1.14 & 1.08 & 0.95 & 1.85 & 0.97 & 0.27 & 1.52 \\
\hline Dy & 6.09 & 8.00 & 4.75 & 3.63 & 3.23 & 4.88 & 3.41 & 3.68 & 3.86 & 9.78 & 4.41 & 1.67 & 6.75 \\
\hline Ho & 0.86 & 1.20 & 0.92 & 0.62 & 0.63 & 0.72 & 0.53 & 0.51 & 0.59 & 2.13 & 0.77 & 0.32 & 1.19 \\
\hline Er & 2.06 & 2.56 & 2.59 & 1.46 & 1.82 & 1.51 & 1.16 & 1.02 & 1.39 & 6.48 & 2.09 & 1.13 & 3.29 \\
\hline $\mathrm{Tm}$ & 0.24 & 0.29 & 0.38 & 0.21 & 0.35 & 0.16 & 0.14 & b.d. & 0.24 & 0.94 & 0.29 & 0.17 & 0.40 \\
\hline $\mathrm{Yb}$ & 1.43 & 1.60 & 2.17 & 1.19 & 2.00 & 1.14 & 0.89 & 0.58 & 1.12 & 5.84 & 1.78 & 1.12 & 2.17 \\
\hline $\mathrm{Lu}$ & 0.20 & 0.20 & 0.33 & 0.21 & 0.31 & 0.15 & 0.11 & b.d. & 0.23 & 0.79 & 0.25 & 0.15 & 0.30 \\
\hline A/CNK & 1.12 & 1.10 & 1.08 & 1.07 & 1.09 & 1.14 & 1.10 & 1.08 & 1.09 & 1.11 & 1.07 & 1.04 & 1.06 \\
\hline $\mathrm{FeO} / \mathrm{MgO}$ & 4.95 & 7.89 & 7.30 & 6.62 & 4.65 & 5.41 & 5.65 & 5.39 & 4.80 & 10.1 & 4.96 & 6.78 & 4.62 \\
\hline$(\mathrm{La} / \mathrm{Yb})_{\mathrm{N}}$ & 31.0 & 40.6 & 15.3 & 26.7 & 13.5 & 52.1 & 50.1 & 69.5 & 51.6 & 18.1 & 47.9 & 33.7 & 44.3 \\
\hline $\mathrm{Eu} / \mathrm{Eu}^{*}$ & 0.13 & 0.08 & 0.17 & 0.16 & 0.40 & 0.16 & 0.14 & 0.16 & 0.24 & 0.18 & 0.28 & 0.13 & 0.24 \\
\hline
\end{tabular}

b.d. = below detection limit. $\mathrm{N}=$ number of samples. Total $\mathrm{Fe}$ is expressed as $\mathrm{FeO}_{\text {tot }} \cdot \mathrm{A} / \mathrm{CNK}=$ molecular $\mathrm{Al}_{2} \mathrm{O}_{3} /\left(\mathrm{CaO}+\mathrm{Na}_{2} \mathrm{O}+\mathrm{K}_{2} \mathrm{O}\right)$. $\mathrm{Chondrite}-\mathrm{normalizing}$ values from Boynton (1984).

Data of the Nagu granite from Stålfors \& Ehlers (2006) and of the Karjaa granite from Jurvanen et al. (2005). 
$\mathrm{Y}$ and $\mathrm{Fe} / \mathrm{Mg}$ and lower in $\mathrm{Ti}$ and $\mathrm{Mg}$ than the granites (Fig. 6, Table 1). The crosscutting felsic vein in the Haapajärvi granite (HG2/f2 in Table 1) is anomalous having high $\mathrm{Ca}$ and $\mathrm{Zr}$, and low $\mathrm{K}, \mathrm{Ba}$ and $\mathrm{Rb}$ content (the small size of this sample reduces the representativeness of the composition).
The Nagu granite is geochemically similar to the Haapajärvi, Evitskog and Kylmälä granites (Fig. 6). The felsic layers in the Nagu granite are similar to the felsic layers in Veikkola being lower in $\mathrm{Ti}$ and $\mathrm{Mg}$ and higher in Fe/Mg than the host porphyritic granite (Table 1). The Karjaa granite differs from the Veikko-
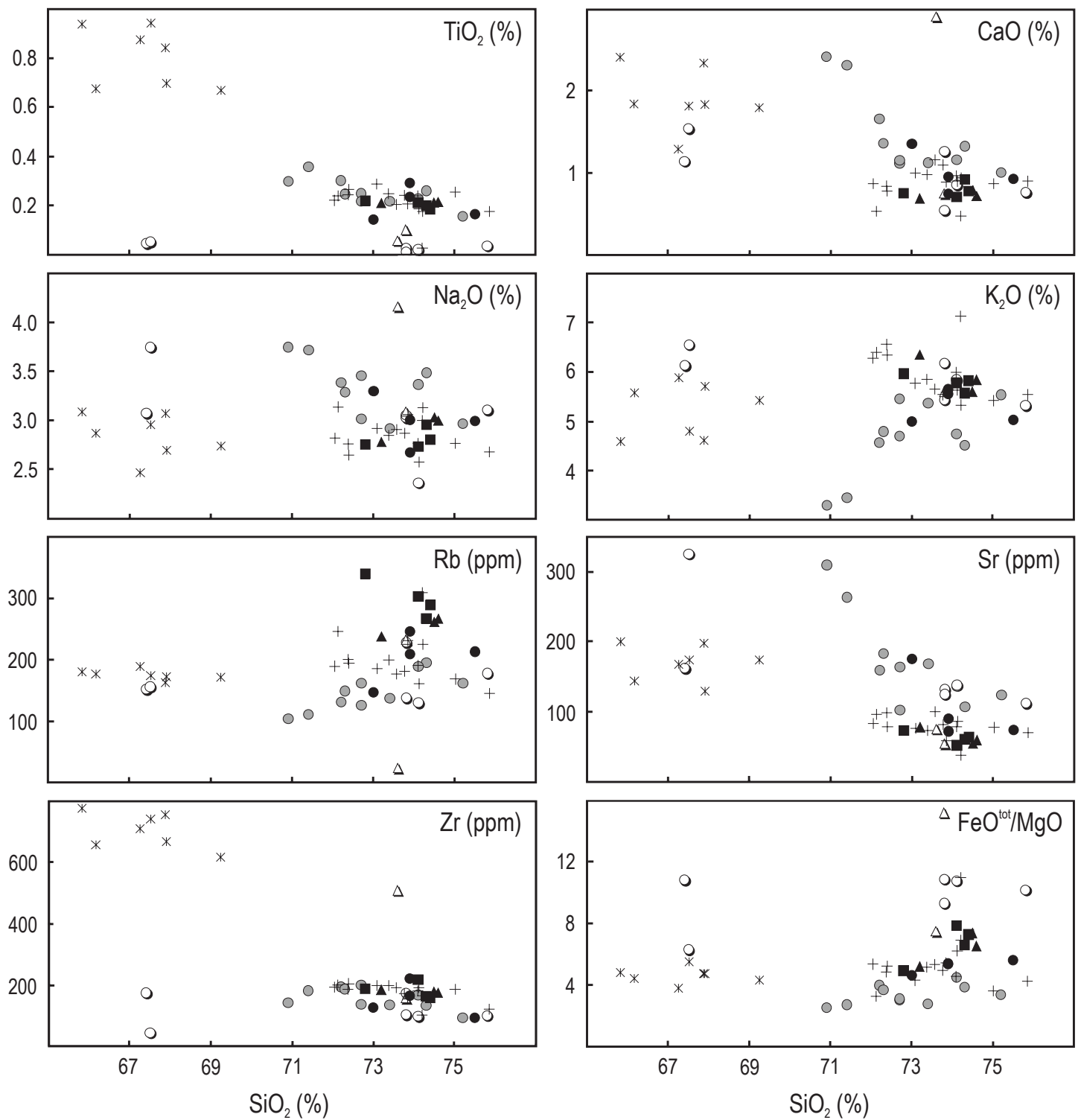

- Nuuksio granite

- Nuuksio granite, felsic layer

- Evitskog granite
- Haapajärvi granite

$\Delta$ Haapajärvi granite, felsic vein

- Kylmälä granite
+ Nagu granite

* Karjaa granite

Fig. 6. Geochemical discrimination diagrams on the Veikkola granites. Data of the Nagu granite (Stålfors \& Ehlers, 2006) and Karjaa granite (Jurvanen et al., 2005) are shown for comparison. 

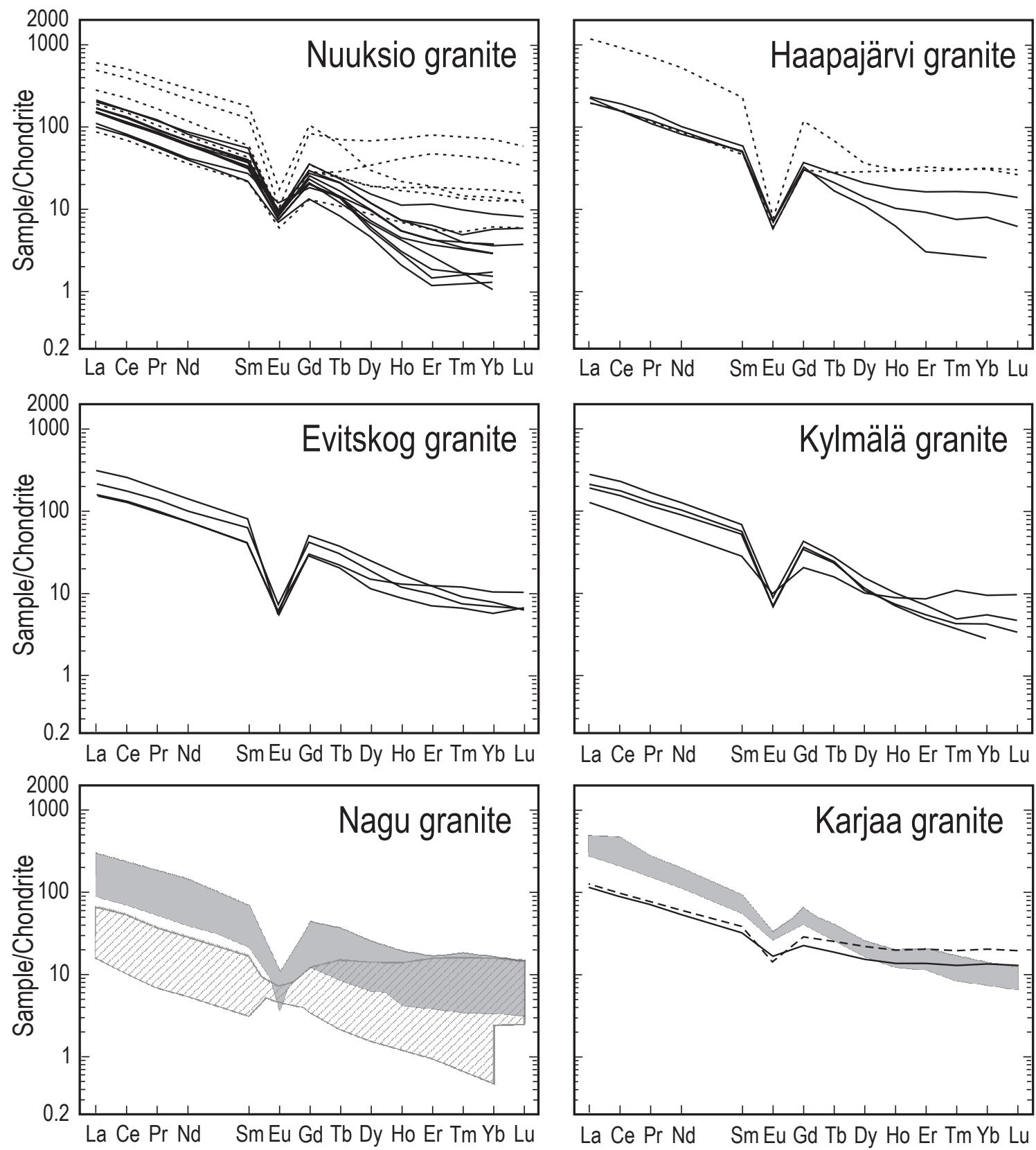

Fig. 7. Rare earth element (REE) patterns of the Veikkola granites, normalized against chondrite (Boynton, 1984). The patterns of the felsic layers/veins in the Nuuksio and Haapajärvi granites are shown by dotted lines. In the diagram of the Nagu granites the shadowed and lined areas show the patterns of the granites and the felsic veins, respectively (see Stålfors \& Ehlers, 2006). In the diagram of the Karjaa area the shadowed area shows the patterns of the Karjaa granites. The solid line shows the average REE for mica schists and gneisses, and the broken line for quartz-feldspar gneisses of southern Finland (data from the Rock Geochemical Database of Finland, Version I.I. http://www.gtk.fi/publ/RGDB). 
la and Nagu granites having lower Si and higher Ti, $\mathrm{P}$, $\mathrm{Ba}, \mathrm{Zr}, \mathrm{Nb}$, and Y contents (Fig. 6, Table 1).

The REE patterns of the Veikkola granites are similar (Fig. 7). The mean $(\mathrm{La} / \mathrm{Yb})_{\mathrm{N}}$ ratio for the granites (51.6) does not differ much from the mean ratios in the Nagu and Karjaa granites (Table 1). The granites have strong negative Eu anomalies (mean $\mathrm{Eu} / \mathrm{Eu}^{*}$ ratio 0.24$)$, similar to the values in the Nagu granite; the Eu anomaly is smaller in the Karjaa granite. The felsic layers in the Nuuksio and Haapajärvi granites are higher in REE than the host granites and have lower $(\mathrm{La} / \mathrm{Yb})_{\mathrm{N}}$ ratios (mean 18.1), unlike in the Nagu granite, where the felsic layers have lower REE contents compared to their host granites.

\subsection{Enderbite}

The geochemistry of the enderbite samples are shown in Table 2 and Fig. 8. Their geochemistry is compared with the geochemistry of gneisses around the Veikkola granites and with $1815 \mathrm{Ma}$ monzogranites around Turku that are coeval (but not cogenetic) with lateorogenic granites in that area (Väisänen et al., 2000).

The enderbite has an intermediate composition with $\mathrm{SiO}_{2}$ between $59-66$ wt.\%. As can be seen in Fig. 8a, the enderbite differs from the surrounding gneisses having higher $\mathrm{Ti}$ (and $\mathrm{Fe}$ ) contents within the limited $\mathrm{SiO}_{2}$ range. The Ti contents of the enderbite and the Turku monzodiorites conform to the general decreasing trend of magmatic rocks with increasing $\mathrm{SiO}_{2}$. However, the $\mathrm{Ba}$ (as well as $\mathrm{P}, \mathrm{Sr}$ and $\mathrm{Nb}$ ) contents of the Turku monzodiorites are much higher than those in the enderbites (Fig. 8b). The REE pattern of the enderbites complies neither with the Turku monzodiorites nor with the surrounding gneisses (Figs. 8c and 8d).

\section{Mineral chemistry}

The garnet-biotite-plagioclase-quartz geobarometry (GBPQ) of Wu et al (2004) was applied to samples of the Nuuksio, Haapajärvi and Evitskog granites, as well as to migmatitic garnet-cordierite paragneisses to the northwest of the Veikkola granite area.
Table 2. Chemical composition of enderbites in the Veikkola area.

\begin{tabular}{|c|c|c|c|}
\hline Sample & $57 / 03$ & $1 / 06$ & $4 / 06$ \\
\hline $\mathrm{SiO}_{2}$ (wt.\%) & 62.4 & 59.0 & 66.0 \\
\hline $\mathrm{TiO}_{2}$ & 1.18 & 1.56 & 0.91 \\
\hline $\mathrm{Al}_{2} \mathrm{O}_{3}$ & 15.5 & 15.1 & 15.0 \\
\hline $\mathrm{FeO}_{\text {tot }}$ & 6.86 & 9.05 & 4.93 \\
\hline $\mathrm{MnO}$ & 0.08 & 0.12 & 0.06 \\
\hline $\mathrm{MgO}$ & 2.57 & 2.98 & 1.88 \\
\hline $\mathrm{CaO}$ & 5.40 & 6.22 & 4.04 \\
\hline $\mathrm{Na}_{2} \mathrm{O}$ & 3.22 & 3.12 & 2.90 \\
\hline $\mathrm{K}_{2} \mathrm{O}$ & 1.40 & 1.21 & 3.22 \\
\hline $\mathrm{P}_{2} \mathrm{O}_{5}$ & 0.171 & 0.163 & 0.155 \\
\hline $\mathrm{F}$ & 0.081 & 0.106 & 0.059 \\
\hline $\mathrm{Cl}$ & 0.015 & 0.014 & 0.009 \\
\hline S & 0.041 & 0.068 & 0.038 \\
\hline C & 0.059 & 0.064 & 0.039 \\
\hline Mg number & 0.40 & 0.37 & 0.40 \\
\hline$S(\mathrm{ppm})$ & 41 & 68 & 38 \\
\hline $\mathrm{Ba}$ & 112 & 120 & 338 \\
\hline $\mathrm{Rb}$ & 76 & 62 & 124 \\
\hline $\mathrm{Sr}$ & 202 & 242 & 205 \\
\hline V & 106 & 151 & 92 \\
\hline $\mathrm{Cr}$ & 69 & 76 & 52 \\
\hline $\mathrm{Ni}$ & 39 & 40 & 34 \\
\hline $\mathrm{Zn}$ & 109 & 119 & 90 \\
\hline $\mathrm{Zr}$ & 123 & 125 & 16 \\
\hline $\mathrm{Nb}$ & 13 & 11 & 21 \\
\hline Y & 15 & 22 & 11 \\
\hline $\mathrm{Hf}$ & 2.95 & 3.18 & b.d. \\
\hline $\mathrm{Ta}$ & 0.74 & 0.55 & 0.88 \\
\hline Th & 7.31 & 8.41 & 1.68 \\
\hline $\mathrm{U}$ & 1.37 & 0.76 & 0.28 \\
\hline $\mathrm{La}$ & 21.2 & 25.6 & 18.6 \\
\hline $\mathrm{Ce}$ & 47.1 & 58.3 & 40.2 \\
\hline $\operatorname{Pr}$ & 6.02 & 7.02 & 5.11 \\
\hline $\mathrm{Nd}$ & 24.8 & 28.9 & 20.7 \\
\hline $\mathrm{Sm}$ & 5.56 & 6.92 & 4.82 \\
\hline $\mathrm{Eu}$ & 1.00 & 1.32 & 0.95 \\
\hline $\mathrm{Gd}$ & 5.60 & 7.02 & 4.98 \\
\hline $\mathrm{Tb}$ & 0.77 & 1.00 & 0.63 \\
\hline Dy & 3.49 & 4.84 & 3.45 \\
\hline Ho & 0.66 & 0.91 & 0.55 \\
\hline Er & 1.52 & 2.27 & 1.41 \\
\hline $\mathrm{Tm}$ & 0.21 & 0.30 & 0.18 \\
\hline $\mathrm{Yb}$ & 1.34 & 1.74 & 1.05 \\
\hline $\mathrm{Lu}$ & 0.20 & 0.28 & 0.13 \\
\hline
\end{tabular}

Total $\mathrm{Fe}$ is expressed as $\mathrm{FeO}_{\text {tot }}$. b.d. = below detection limit. 

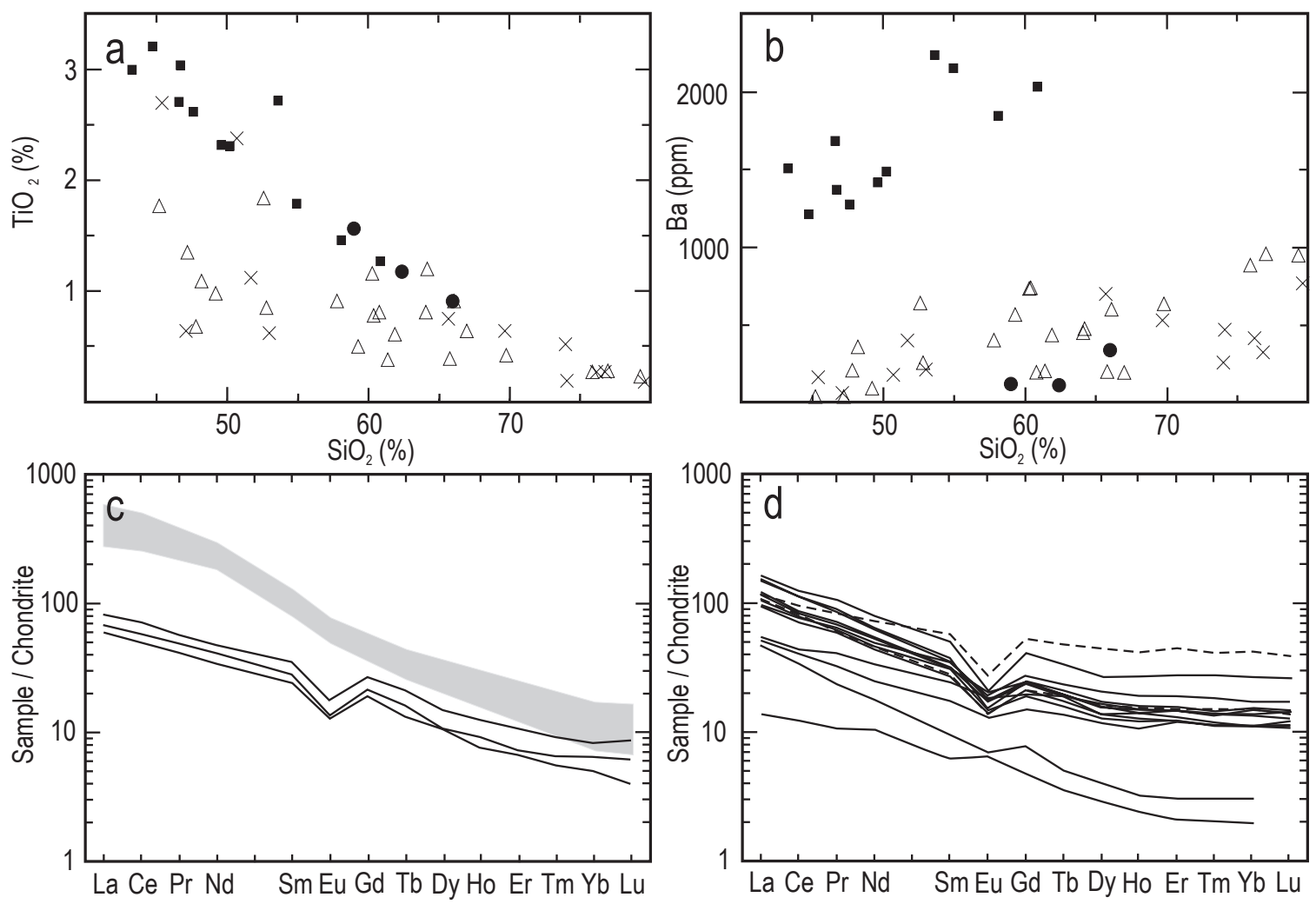

Fig. 8. Geochemical diagrams on the enderbite in the Veikkola granite area, host gneisses (amphibolites, hornblende gneisses and felsic gneisses; data from the Rock Geochemical Database of Finland,Version I.I. http://www.gtk.fi/publ/ RGDB) and monzodiorites of the Turku area (data from Väisänen et al., 2000). a) $\mathrm{TiO}_{2} \mathrm{vs}^{\text {. SiO }} \mathrm{S}_{2}$ Solid circles $=\mathrm{Veik}$ kola enderbite, open triangles = gneisses north of the Veikkola granites (West Uusimaa Complex), crosses = gneisses south of the Veikkola granites, solid squares = monzodiorites of the Turku area. b) $\mathrm{Ba}_{\mathrm{vs}}$. SiO $\mathrm{S}_{2}$ c) $\mathrm{REE}_{\mathrm{a}}$ composition of the Veikkola enderbites (solid lines) and Turku monzodiorites (shaded area), normalized against chondrite (Boynton 1984). d) REE composition of the gneisses with $\mathrm{SiO}_{2}$ between $55 \%$ and $70 \%$ around the Veikkola granites. Solid lines $=$ gneisses north of the Veikkola granites, broken lines = gneisses south of the Veikkola granites .

The barometric algorithm utilizes the garnet-biotite temperatures of Holdaway (2000). For comparison, temperatures from another garnet-biotite calibration by Bhattacharya et al. (1992) as well as zircon saturation temperatures (Watson \& Harrison, 1983) from the whole-rock chemistry were calculated for the granites. In addition, garnet zonation was studied from the migmatites and granites. All mineral analyses were performed with the Cameca SX100 electron microprobe of the GTK. The data are presented in Appendixes 1 and 2. The selection of samples for thermobarometry calculations was limited by the absence of biotite in many leucocratic samples.

\section{I.Thermobarometry}

Garnet, biotite and plagioclase compositions from five granites samples (two of these are from felsic layers) and five samples from the adjoining migmatitic rocks (two from a mesosome-leucosome pair) were analyzed. The mineral compositions and the results of the thermobarometry study are presented in Appendix 1 and Table 3, respectively. The majority of the pressure results for the granites are between 4.6 and 6.5 kbar which appears a reasonable estimate (cf. Selonen et al., 1996; Stålfors \& Ehlers, 2006) while slightly lower pressures of $3.2-4.4 \mathrm{kbar}$ were 
obtained from the migmatites (Fig. 9). The wider pressure range for the granites likely results from incipient alteration of biotite. In the barometric results the Evitskog granite sample (EG2) is an obvious outlier. Probably later events have affected its plagioclase which is extremely sodic. As the GBPQ barometer requires plagioclase to have $\mathrm{X}_{\mathrm{An}} \geq 17 \%$ (Wu et al., 2004), this result cannot be considered reliable. Addi- tionally, the $\mathrm{X}_{\mathrm{Grs}}$ in garnet should be $\geq 3 \%$, and some of the migmatites are at or slightly below this limit. The felsic vein in the Haapajärvi granite (HG2/f1) gives anomalously low pressure and temperature. $\mathrm{Bi}$ otite in this sample is more altered than in the others and is not in contact with garnet and plagioclase, hence the results for this rock are suspect.

Table 3. Thermobarometry calculations on granites in the Veikkola area (first five samples, sample codes as in Table I) and on garnet-cordierite migmatites northwest of the Veikkola granite area.

\begin{tabular}{lllllllllll}
\hline \multicolumn{3}{c}{ Granites } & \multicolumn{7}{c}{ Migmatites } \\
& NG3/f & NG6 & NG7 & EG2 & HG2/f1 & M1 & M2 & M3 & M4 & M4/f \\
\hline $\mathrm{P}(\text { bars })^{1)}$ & 4671 & 4617 & 6527 & 13171 & 1380 & 3354 & 3911 & 3202 & 3827 & 4373 \\
& & & & & & & & & & \\
$\mathrm{~T}\left({ }^{\circ} \mathrm{C}\right)^{2)}$ & 678 & 636 & 701 & 656 & 529 & 623 & 668 & 632 & 690 & 640 \\
$\mathrm{~T}\left({ }^{\circ} \mathrm{C}\right)^{3)}$ & 696 & 638 & 732 & 629 & 527 & 637 & 684 & 638 & 723 & 653 \\
$\mathrm{~T}\left({ }^{\circ} \mathrm{C}\right)^{4)}$ & 797 & 755 & 749 & 820 & 790 & & & & & \\
& & & & & & & & & & \\
\hline
\end{tabular}

${ }^{1)}$ Wu et al., 2004; ${ }^{2)}$ Holdaway, 2000; ${ }^{3)}$ Bhattacharya et al., 1992; ${ }^{4)}$ Watson \& Harrison, 1983

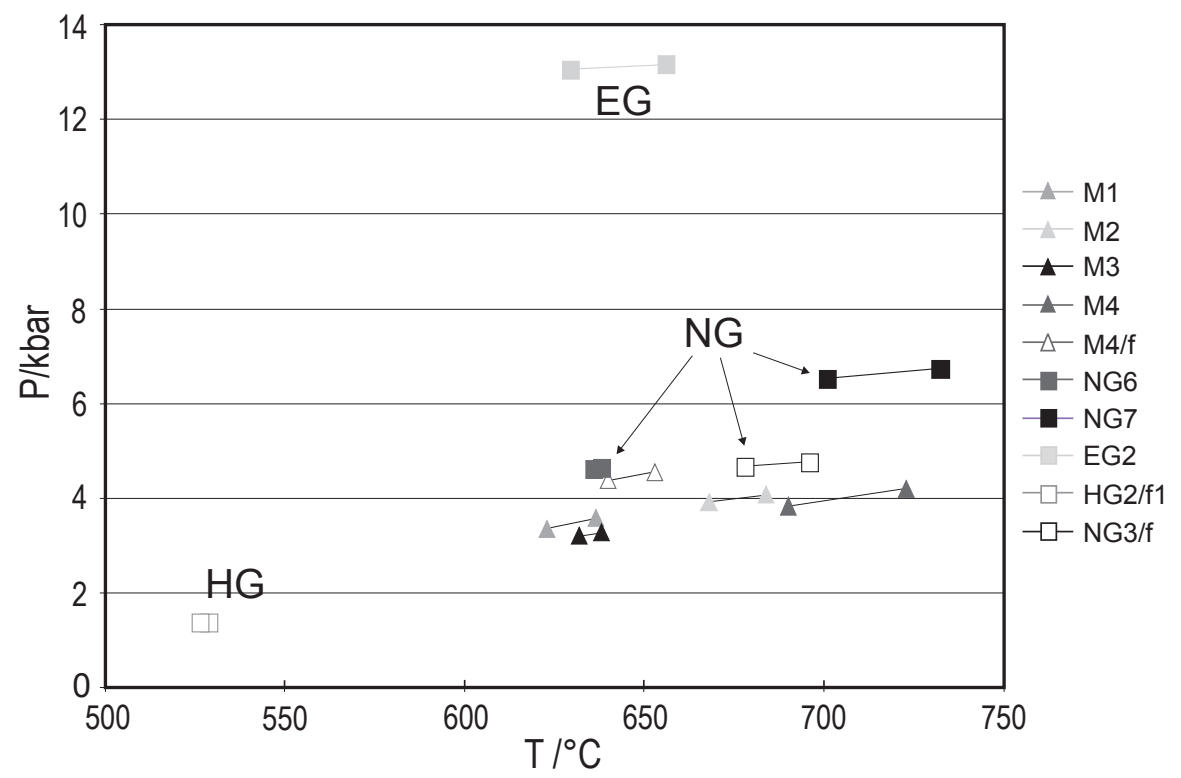

Fig. 9. Thermobarometry resultsof the granites and migmatites in the Veikkola area. $E G=$ Evitskog granite, $H G=$ Haapajärvi granite, NG = Nuuksio granite. The pressure values are from GBPQ geobarometry by Wu et al., (2004), calculated for different garnet-biotite exchange temperatures (Holdaway, 2000; Bhattacharya et al., 1992) The very high pressure of the Evitskog granite sample is not reliable as the mineral compositions in that rock do not meet with the criteria of Wu et al. (2004). 
The garnet-biotite temperature estimates (Holdaway, 2000; Bhattacharya et al., 1992) fall between $620^{\circ} \mathrm{C}$ and $720^{\circ} \mathrm{C}$ for both the granites and the migmatites (with the exception of sample HG2/f1). Again the migmatites have less variation than the granites. The zircon saturation method (Watson \& Harrison, $1983)$ yields higher temperatures $\left(750-820^{\circ} \mathrm{C}\right)$ than the ones based on mineral chemistry.

\subsection{Garnet composition}

In order to assess the origin of the felsic layers in the granites, garnet composition was studied from the host granites, their felsic layers, and mesosomes and leucosomes in the adjacent migmatites. Traverses across garnet grains were analyzed for major elements and Ti, Sr, Zn, Cr and Ni. For this purpose, only unaltered, relatively small, euhedral grains were selected for analysis. The major elements were analyzed from four granites and four migmatite mesosome-leucosome pairs and the trace elements were analyzed from three granites and three migmatite pairs (Appendix 2). The Haapajärvi granite is an exception: because the host granite (sample HG2) does not contain garnet, a felsic vein (sample HG2/f1; see Fig. 3d) and a crosscutting granitic vein (HG2/f2) were studied.

The mineral chemistry study showed some systematic features. Almandine is the prevalent garnet component in all samples, and the Fe content is higher in granites than in migmatites (Appendix 2). Towards the rim, all the garnets from felsic parts of the granites show an increase of almandine at the expense of pyrope, whereas the migmatites have mostly homogeneous distribution of the garnet components (Fig. 10). The Ca and Mn contents are generally low but slightly higher in the granites than in the migmatites. The felsic layers of the Nuuksio granites show an increase in Mn towards the rims whereas in the other samples the profiles are flat. Most of the trace element compositions vary along the profiles (not shown) but only Cr shows a systematic trend, being higher in migmatites than in the granites, in which the profiles are flat and low. The $\mathrm{Ti}$ and $\mathrm{Zn}$ distributions do not follow easily recognizable patterns. $\mathrm{Sr}$ and $\mathrm{Ni}$ are at or below detection limits in all the garnet samples.

\section{Discussion}

\section{I.Thermobarometry results and origin of garnet}

The garnet-biotite temperatures (Bhattacharya et al., 1992; Holdaway, 2000) for the granitic rocks cover a wide range from $530^{\circ} \mathrm{C}$ to $740^{\circ} \mathrm{C}$, and the GBPQ barometer (Wu et al., 2004) indicates that the rocks crystallized at 4.6 to $6.5 \mathrm{kbar}$, corresponding to crustal depths of $17-25 \mathrm{~km}$. The highest pressure was obtained from the Nuuksio granite whereas a felsic layer of the same granite yielded $\sim 1.5 \mathrm{kbar}$ lower pressure (Fig. 9). As the garnet in the granites shows features of retrogression (elevated Mn and decreasing Mg at the rim; e.g., Pyle \& Spear, 1999), we do not consider the temperature results peak temperatures of the granite-forming event. Rather, they represent the solidus temperature of the felsic layers. It should be noted that the garnet compositions used for the PT calculations are averages of measurements from generally small grains. If only the retrograde rim compositions would be used, the temperatures would be even lower. Experimental results (Vielzeuf \& Holloway, 1988; Patiño Douce \& Johnston, 1991; Patiño Douce \& Beard, 1995) imply temperatures above $850^{\circ} \mathrm{C}$ for crustal-derived peraluminous granitic magmas, which are considerably higher than any of the present results and further emphasizes the retrograde nature of the granites studied here. Since the migmatite samples are unaltered and their temperature results plot in a relatively narrow range, we interpret their temperature estimates $\left(650-700^{\circ} \mathrm{C}\right)$ as segregation temperatures of the leucosomes.

The model of Watson \& Harrison (1983) is supposed to yield the temperature at which zircon is in equilibrium with the granitic melt. However, during low-temperature crustal melting the amount of accessory phases such as $\mathrm{Zr}$ is not sufficient for saturation (e.g. Bea, 1996). This may explain why the temperatures from the Veikkola granites $(750-$ $820^{\circ} \mathrm{C}$ ) are lower than those obtained from experi- 

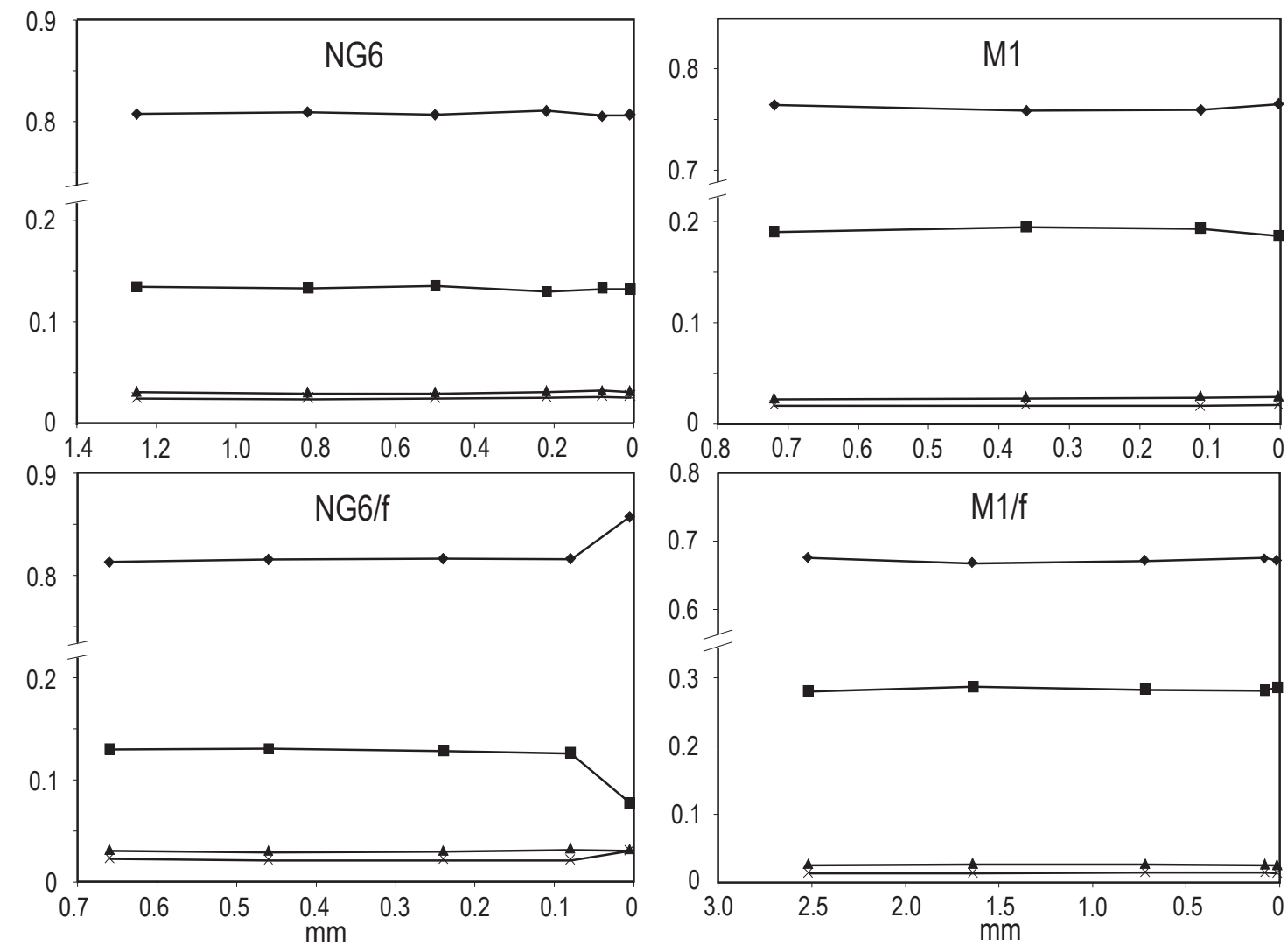

core

rim

core

rim

- Almandine - Pyrope $\Delta$ Grossular $\times$ Spessartine

Fig. 10. Representative major element profiles across garnet crystals in the Nuuksio granite and adjacent migmatitic garnet-cordierite gneiss.

ments $\left(\geq 850^{\circ} \mathrm{C}\right)$. Another limitation of the method is that the amount of inherited zircon cannot be assessed (see Clemens, 2003). In our previous U-Pb studies of these granites (Kurhila et al., 2005) only the Nuuksio granite turned out to contain some inherited zircon.

Stålfors \& Ehlers (2006) interpreted that garnet in the Nagu granite is restitic; it stems from surrounding migmatites and was shielded by biotite. Garnet occurs in the Veikkola granites as anhedral to subhedral grains, or as cores of biotite aggregates. If garnet was restitic, entrapped in mafic minerals, it would be fine-grained. However, garnet is fairly coarse and also differs in composition from garnet in adjacent migm- atites (Fig. 10). Therefore, we infer that garnet in the granites mainly crystallized from melt. The biotite aggregates with garnet cores are likely the result of retrograde alteration.

Garnet is more idiomorphic in the felsic layers and veins compared to the host granites, implying partial crystallization from the melt. As already noted, garnet in the felsic layers of the Nuuksio granite displays a slight increase in $\mathrm{Mn}$ at the rim, which is likely the result of retrograde reactions because in growth zoning a decrease of $\mathrm{Mn}$ content would be expected. This corroborates that garnet grains and aggregates in the felsic layers of the Nuuksio granite crystallized from melt. 


\subsection{Heterogeneity and origin of the granites and enderbite}

A typical feature of the lateorogenic granites is their chemical heterogeneity within their restricted $\mathrm{SiO}_{2}$ range (71 - 78 wt.\%; Lahtinen, 1996; Johannes et al., 2003). This holds also for the Veikkola granites (Fig. 6). The higher $\mathrm{Na}_{2} \mathrm{O}, \mathrm{CaO}$ and $\mathrm{Sr}$ values of the Nuuksio granite indicate higher plagioclase content compared to the other Veikkola granites. Lahtinen (1996) studied the geochemistry of the lateorogenic granites around Hämeenlinna, $70 \mathrm{~km}$ north of the Veikkola area (Fig. 1). He divided the granites into high- $\mathrm{K}_{2} \mathrm{O}$ and very high- $\mathrm{K}_{2} \mathrm{O}$ groups (boundary at $\sim 5$ wt. $\% \mathrm{~K}_{2} \mathrm{O}$ ), the latter characterized by higher $\mathrm{TiO}_{2}, \mathrm{Zr}, \mathrm{La}$, Th and $\mathrm{U}$, suggesting higher melting temperatures. This grouping is not valid for the Veikkola granites: the Haapajärvi and Evitskog granites have high $\mathrm{K}_{2} \mathrm{O}$ values $(5.5-6.4$ wt.\%) and the Evitskog granite has high $U$ values $(3.1-10.2 \mathrm{ppm}$ ) but the $\mathrm{TiO}_{2}, \mathrm{Zr}$ and $\mathrm{Th}$ contents are fairly similar in all Veikkola granites.

Contrary to the heterogeneity of major, minor and trace element compositions of the Veikkola granites, their REE patterns are fairly similar (Fig. 7). The Nagu granite shows a similar REE pattern whereas the REE level of the Karjaa granite is higher. In contrast to the Nagu granites, where the REE contents of felsic veins are below those of the host granites and without a negative Eu anomaly, the REE contents in the felsic layers and veins in the Nuuksio and Haapajärvi granites are above those in the host granites and show a deep Eu anomaly. This difference implies fundamentally different origin for the felsic layers and veins in the Veikkola and Nagu areas. In high- $\mathrm{SiO}_{2}$ granites the REE patterns are mainly controlled by the accessory phases monazite, zircon and allanite (except for Eu which is controlled by feldspar fractionation). Fractionation of garnet, zircon and monazite likely accounts for the significant variation in HREE in the Nuuksio and Haapajärvi granites (both host granites and felsic layers and veins). The higher REE contents in the felsic layers may be best explained by derivation from the host granite.
Partial melting of supracrustal (mainly sedimentary) rocks, leaving a garnet-bearing source residue, has been proposed for the origin of the lateorogenic granites in southern Finland (Nurmi \& Haapala, 1986; Lahtinen, 1996). The LREE contents of the Veikkola as well as the Nagu and Karjaa granites are generally higher and HREE contents lower compared to the average REE patterns of supracrustal gneisses of southern Finland (Fig. 7). Thus the REE evidence does not contradict with the assumption above.

The Nuuksio and Haapajärvi granite magmas were likely water-undersaturated because garnet is a common mineral in both the host granites and the felsic layers and veins. On the basis of experimental results, large volumes of peraluminous granitic magma may be generated by dehydration melting reactions in crustal rocks. Metapelites are the most fertile source rocks for granites above $850^{\circ} \mathrm{C}$ and between 7 and $10 \mathrm{kbar}$, being able to produce up to $60 \mathrm{vol} . \%$ of peraluminous, leucocratic granitic melts (Vielzeuf \& Holloway, 1988; Patiňo Douce \& Johnston, 1991). Below 7 kbar metagreywackes are almost as fertile as metapelites (Vielzeuf \& Montel, 1994; Montel \& Vielzeuf, 1997). However, within ranges $7-8 \mathrm{kbar}$ and $850-950^{\circ} \mathrm{C}$ melts from metapelites are more strongly peraluminous (A/CNK $1.30-1.64)$ than melts from metagreywackes $(1.15-1.22$; Table 4$)$; both are more peraluminous than the Veikkola granites $(1.06-1.14)$. Moreover, Fe/Mg ratios are lower in the metagreywackes than in the Veikkola granites (Table 4). A closer analogue in melt composition is a granodioritic gneiss with marginally peraluminous character and $\mathrm{Fe} / \mathrm{Mg}$ ratios close to the ones in the Veikkola granites (Beard et al., 1993). The granodiorite gneiss samples were rather refractory and produced only $5-25 \%$ melt at $6.9 \mathrm{kbar}$ and $900-950^{\circ} \mathrm{C}$. A synthetic biotite gneiss produced up to $20 \%$ of leucocratic, peraluminous granitic melt at $5-7 \mathrm{kbar}$ and $900^{\circ} \mathrm{C}$ during fluid-absent melting (Patiňo Douce $\&$ Beard, 1995), with $\mathrm{A} / \mathrm{CNK}$ and Fe/Mg ratios close to the values in the Veikkola granites. On the basis of the experimental data we infer that partial melting of a metagreywacke-dominated layered rock sequence rather than a single rock type produced the Veikko- 
la granites. Analogues of such layered rocks, with metapelite and amphibole gneiss interlayers in a metagreywacke, are common in the bedrock of southern Finland.

In the experiments cited above, biotite breakdown reaction with both metapelite and metagreywacke as starting materials produced garnet and melt (and Kfeldspar). Such a reaction would also explain the occurrence of garnet in the Veikkola granites.

The enderbite shows contact relationships to host granites that suggest injection as subhorizontal sills coeval with the Haapajärvi granite, and restricted magma mixing during injection. Väisänen \& Hölttä (1999; Figs. 7d and 7e) reported a similar case among the $1815 \mathrm{Ma}$ Turku granites and monzodiorites. However, the Turku monzodiorites differ from the Veikkola enderbite in their shoshonitic affinity. The fact that the enderbite differs in chemical composition from adjacent gneisses indicates that melting of host rocks below the granites did not produce the enderbite; it must have a deeper source. The origin of the enderbite remains unclear.

Table 4. Comparison of major elements in the Veikkola granites (mean values) and in various experimentally melted rocks. Experimental data from Patiño Douce \& Johnston, 199I; Beard et al., 1993; Patiño Douce \& Beard, 1995; and Montel \& Vielzeuf, 1997.

\begin{tabular}{|c|c|c|c|c|c|c|c|c|c|c|c|c|}
\hline & $\begin{array}{r}\mathrm{P}(\mathrm{kbar}) / \\
\mathrm{T}\left({ }^{\circ} \mathrm{C}\right)\end{array}$ & $\mathrm{SiO}_{2}$ & $\mathrm{TiO}_{2}$ & $\mathrm{Al}_{2} \mathrm{O}_{3}$ & $\mathrm{FeO}_{\text {tot }}$ & $\mathrm{MgO}$ & $\mathrm{CaO}$ & $\mathrm{Na}_{2} \mathrm{O}$ & $\mathrm{K}_{2} \mathrm{O}$ & $\begin{array}{l}\mathrm{FeO} / \\
\mathrm{MgO}\end{array}$ & A/CNK & $\begin{array}{r}\mathrm{TiO}_{2} \\
+\mathrm{FeO} \\
+\mathrm{MgO} \\
\end{array}$ \\
\hline Nuuksio granite & & 72.9 & 0.25 & 14.2 & 1.53 & 0.47 & 1.47 & 3.34 & 4.65 & 3.38 & 1.08 & 2.26 \\
\hline Haapajärvi granite & & 74.1 & 0.21 & 13.7 & 1.48 & 0.24 & 0.73 & 2.94 & 5.93 & 6.36 & 1.09 & 1.93 \\
\hline Evitskog granite & & 73.9 & 0.20 & 13.5 & 1.81 & 0.28 & 0.79 & 2.82 & 5.79 & 6.69 & 1.10 & 2.29 \\
\hline Kylmälä granite & & 74.1 & 0.21 & 13.8 & 1.67 & 0.32 & 1.00 & 3.00 & 5.31 & 5.27 & 1.10 & 2.20 \\
\hline \multicolumn{13}{|l|}{$\begin{array}{l}\text { Patino Douce \& } \\
\text { Johnston, 1991: }\end{array}$} \\
\hline metapelite & $7 / 850$ & 70.1 & 0.10 & 13.3 & 1.55 & 0.33 & 0.30 & 2.23 & 5.60 & 4.70 & 1.30 & 1.98 \\
\hline metapelite & $7 / 875$ & 69.7 & 0.13 & 14.9 & 1.65 & 0.35 & 0.35 & 1.77 & 5.61 & 4.71 & 1.54 & 2.13 \\
\hline metapelite & $7 / 900$ & 70.9 & 0.38 & 13.7 & 1.72 & 0.35 & 0.24 & 1.32 & 5.31 & 4.91 & 1.64 & 2.45 \\
\hline metapelite & $7 / 950$ & 71.4 & 0.28 & 13.8 & 1.78 & 0.39 & 0.15 & 0.87 & 6.25 & 4.56 & 1.63 & 2.45 \\
\hline \multicolumn{13}{|l|}{$\begin{array}{l}\text { Montel \& Vielzeuf, } \\
\text { 1997: }\end{array}$} \\
\hline metagreywacke & $8 / 875$ & 71.0 & 0.28 & 14.6 & 1.59 & 0.61 & 0.68 & 3.47 & 5.29 & 2.61 & 1.15 & 2.48 \\
\hline metagreywacke & $8 / 919$ & 70.9 & 0.25 & 14.6 & 1.45 & 0.54 & 0.65 & 3.19 & 5.15 & 2.69 & 1.22 & 2.24 \\
\hline metagreywacke & $8 / 942$ & 70.3 & 0.32 & 14.0 & 1.37 & 0.67 & 0.70 & 3.41 & 4.89 & 2.04 & 1.15 & 2.36 \\
\hline \multicolumn{13}{|l|}{ Beard \& al., 1993: } \\
\hline granodiorite gneiss & $6.9 / 900$ & 74.4 & 0.20 & 13.7 & 1.79 & 0.23 & 0.91 & 2.85 & 5.90 & 7.78 & 1.08 & 2.22 \\
\hline granodiorite gneiss & $6.9 / 925$ & 74.4 & 0.20 & 13.9 & 1.56 & 0.21 & 0.95 & 2.88 & 5.77 & 7.43 & 1.09 & 1.97 \\
\hline granodiorite gneiss & $6.9 / 950$ & 74.3 & 0.15 & 13.8 & 1.50 & 0.28 & 0.75 & 2.90 & 6.16 & 5.36 & 1.08 & 1.93 \\
\hline granodiorite gneiss & $6.9 / 925$ & 73.9 & 0.07 & 15.6 & 0.76 & 0.11 & 2.91 & 3.93 & 3.39 & 6.91 & 1.01 & 0.94 \\
\hline granodiorite gneiss & $6.9 / 950$ & 72.2 & 0.23 & 15.0 & 2.55 & 0.30 & 0.67 & 3.03 & 5.96 & 8.50 & 1.18 & 3.08 \\
\hline \multicolumn{13}{|l|}{$\begin{array}{l}\text { Patino Douce \& } \\
\text { Beard, 1995: }\end{array}$} \\
\hline biotite gneiss & $5 / 875$ & 71.1 & 0.19 & 15.7 & 1.41 & 0.69 & 0.77 & 2.48 & 7.58 & 2.04 & 1.15 & 2.29 \\
\hline biotite gneiss & $5 / 900$ & 73.1 & 0.37 & 14.0 & 1.67 & 0.54 & 0.84 & 2.65 & 6.58 & 3.09 & 1.08 & 2.58 \\
\hline biotite gneiss & $7 / 875$ & 73.3 & 0.41 & 14.7 & 1.96 & 0.83 & 1.49 & 2.05 & 5.12 & 2.36 & 1.26 & 3.20 \\
\hline biotite gneiss & $7 / 900$ & 74.2 & 0.22 & 14.7 & 1.74 & 0.37 & 1.07 & 1.68 & 5.89 & 4.70 & 1.33 & 2.33 \\
\hline
\end{tabular}




\subsection{Layering and tectonic setting of the granites}

Stålfors \& Ehlers (2006) gave a re-interpretation of the granitization hypothesis presented by Edelman (1972) for the Nagu granite. They noted the cumulate-like REE pattern of the felsic veins and in places strong shearing in granite layers and concluded that the granitic melts were squeezed out, transported as small batches from their supracrustal sources, and emplaced as syntectonic fractionated granites and $\mathrm{cu}-$ mulate layers.

Pegmatitic layers with sharp upper boundaries in the Nuuksio granite suggest accumulation of last melt fractions in upper parts and hence the layers have retained their original, syntectonic way-up direction (see Burg, 1991). Since layering within the Nuuksio and Kylmälä granites is in places replaced by a netveined pattern and some crosscutting felsic veins were also found, we infer that the layering developed in an extensional setting.

The mineral chemistry results show that the felsic layers in the Nuuksio granite are not derived from the surrounding paragneisses but rather from the host granite. We offer two alternatives for the layering: (1) residual melt segregation during emplacement of the granite; or (2) deformation-induced melting of the granite. An extensional setting is presumed for both alternatives. Eliasson et al. (2003) interpreted that the Sveconorwegian Bohus granite in SW Sweden was emplaced syntectonically in an extensional regime (similar to alternative 1). Layering as well as abundant garnet in this granite resemble the Nuuksio granite but garnet aggregates in the Bohus granite ovegrow the igneous flow foliation. The abundance of garnet in the felsic layers is in contradiction with the first alternative because residual melts tend to be water-saturated which would lead to replacement of garnet by biotite. The small amount of felsic rock around garnet aggregates in Fig. $3 \mathrm{c}$ implies that a melt fraction has been removed; this could result from extraction of melt along foliation planes or shear zones. Although both alternatives given above are possible, we consider alternative 2 (deformation- induced melting of the previously emplaced granite) a more probable mechanism.

The GBPQ barometry results are relatively independent of the temperature estimates, and the depth of the emplacement may be roughly determined with this method, regardless of when the compositions of the minerals were stabilized. The Nuuksio granite indicates slightly higher pressure than the migmatites or the Haapajärvi granite. As the Nuuksio granite is the oldest one in the of Veikkola granites area (Kurhila et al., 2005), the results suggest that this granite was emplaced at a deeper crustal level than the others. The lower pressure obtained from the felsic vein of the Nuuksio granite suggests that segregation of the felsic layers occurred at a later stage. Formation of compositional layering in the granites probably coincided with migmatization of the surrounding gneisses.

There are no indications of contractional deformation between the emplacement of the Nuuksio and Haapajärvi granites in spite of the $\sim 25 \mathrm{Ma}$ age difference between the two granites. We infer that the emplacement of the Nuuksio granite at $1850 \mathrm{Ma}$ occurred before $\mathrm{D}_{\mathrm{B}}$ deformation. We do not know when extension started but the Nuuksio granite was likely subjected to slow, protracted extension during $D_{B}$ and progressive regional metamorphism at mid-crustal depth. Deformation-induced melting during extension resulted in compositional layering. The felsic veins and dikes in the Haapajärvi granite developed at a late stage of $D_{B}$ at $1825 \mathrm{Ma}$. The Kylmälä granite was emplaced at the end of extension. The Haapajärvi, Evitskog and Kylmälä granites were emplaced at or close to the peak of high grade metamorphism in the West Uusimaa Complex $(1824 \pm 10 \mathrm{Ma}$; Mouri et al., 2005). Static recrystallization during metamorphism effectively obliterated dynamic deformation microstructures that had been formed in the Nuuksio granite during extension. Contractional $\mathrm{D}_{\mathrm{C}}$ deformation followed the emplacement of the granites. Considering the short time interval in emplacement of the Haapajärvi, Evitskog and Kylmälä granites and their similar chemistry, the granites could also be regarded as pulses of a single granite magma. 
The metamorphic texture of the enderbites imples that the at least the Nuuksio and Haapajärvi granites were subjected to granulite facies metamorphism. Thus the area of the West Uusimaa Complex extends to the south of the "orthopyroxene-in" line defined by Schreurs \& Westra (1986). The mica gneiss in host rock raft in the southwestern part of the Veikkola area, with mineralogy consistent with amphibolite facies peak metamorphic conditions, sets the southern boundary of the West Uusimaa Complex.

As data accumulates, the tectonic history of southern Finland seems increasingly complex (cf. Väisänen et al., 2000; Lahtinen et al., 2005; Skyttä et al., 2006; Stålfors \& Ehlers, 2006). Recent studies on detrital zircons in metasandstones of southern Finland and central Sweden imply that intra-orogenic sedimentary basins existed $1.86-1.83 \mathrm{Ga}$ ago, between the emplacement of the synorogenic and lateorogenic granitoids (Bergman et al., 2008). Based on structural and isotopic studies, Skyttä and Mänttäri (in print) concluded that extension and most voluminous granite magmatism around Karjaa occurred during 1835 $1825 \mathrm{Ma}$ and that a shift to contraction took place at $\sim 1820 \mathrm{Ma}$. These time estimates correlate well with the conclusions of this study and constrain the onset of extension to $\sim 15 \mathrm{Ma}$ after emplacement of the Nuuksio granite. Transpressional environment has previously been offered for emplacement setting of lateorogenic granites in southwestern Finland (Ehlers et al., 1993). In the light of this study, it is quite possible that the lateorogenic granites were emplaced in different tectonic settings over the entire Late Svecofennian granite-migmatite zone.

\section{Conclusions}

Our studies on the Veikkola granite area suggest the following:

1. Four different flat-lying granite bodies are present in the area. They can be distinguished by petrographic, geochemical and geochronological criteria; the layered Nuuksio granite is $\sim 25 \mathrm{Ma}$ older than the other three granites. In addition, minor enderbite intrusions, coe- val with the younger granites, are present within the granite bodies.

2. Four deformation stages $\left(D_{A}-D_{D}\right)$ can be discerned in the area. $\mathrm{D}_{\mathrm{B}}$ deformation was extensional whereas $\mathrm{D}_{\mathrm{C}}$ and $\mathrm{D}_{\mathrm{D}}$ were contractional.

3. The granites are peraluminous and have high $\mathrm{SiO}_{2}$ contents. They are heterogeneous in terms of major and trace element compositions but fairly similar in their REE patterns. The REE patterns as well as mineral chemistry results suggest that the felsic layers in the oldest granites were derived from the host granite. The granites were probably derived by dehydration melting of layered, greywacke-dominated rocks. Melting was fluid-absent both during the generation of the granites and during formation of the felsic layers.

4. According to thermobarometry, based on garnet, biotite and plagioclase compositions, the granites were emplaced at crustal depths of $17-$ $25 \mathrm{~km}$ and at temperatures of $\sim 650-700^{\circ} \mathrm{C}$. The higher PT results for the Nuuksio granite (6.5 kbar) compared to the Haapajärvi granite and to the adjacent migmatites $(3-5 \mathrm{kbar})$ are compatible with its older age.

5. The oldest Nuuksio granite (1850 Ma) was emplaced at mid-crustal depth before extensional $\mathrm{D}_{\mathrm{B}}$ deformation. Compositional layering in the Nuuksio granite is probably the result of deformation-induced melting that occurred at a higher crustal level than emplacement of the granite, during protracted extension $\left(\mathrm{D}_{\mathrm{B}}\right)$ and progressive regional metamorphism. The other three granites and the enderbite were probably emplaced at a late stage of $D_{B}$, at or close to the peak of metamorphism $(1824 \pm 10 \mathrm{Ma})$.

\section{Acknowledgements}

We wish to thank Bo Johanson and Lassi Pakkanen for performing the electron microprobe analyses. We are also grateful for discussions with Pentti Hölttä and Raimo Lahtinen. The manuscript benefitted from the comments of the journal referees Pietari Skyttä and 
Olav Eklund. Matti Kurhila was funded by the Academy of Finland, Project 54088.

\section{References}

Bea, F., 1996. Controls on the trace element composition of crustal melts. Transactions of the Royal Society of Edinburgh: Earth Sciences 87, 33-41.

Beard, J.S., Abitz, R.J. \& Lofgren, G.E., 1993. Experimental melting of crustal zenoliths from Kilbourne Hole, New Mexico and implications for the contamination and genesis of magmas. Contributions to Mineralogy and Petrology $115,88-102$.

Bergman, S., Högdahl, K., Nironen, M., Ogenhall, E., Sjöström, H., Lundqvist, L. \& Lahtinen, R., 2008. Timing of Palaeoproterozoic intra-orogenic sedimentation in the central Svecofennian Shield; evidence from detrital zircon in metasandstone. Precambrian Research 161, 231-249.

Bhattacharya, A., Mohanty, L., Maji, A., Sen, S.K. \& Raith, M., 1992. Non-ideal mixing in the phlogopite-annite binary: constraints from experimental data on $\mathrm{Mg}-\mathrm{Fe}$ partitioning and reformulation of the biotite-garnet geothermometer. Contributions to Mineralogy and Petrology 111, 87-93.

Boynton, W.V., 1984. Geochemistry of the rare earth elements: meteorite studies. In: Henderson, P. (ed.) Rare Earth Element Geochemistry. Elsevier, Amsterdam, 63-114.

Burg, J.-P., 1991. Syn-migmatization way-up criteria. Journal of Structural Geology 13, 617-623.

Clarke, D.B. \& Clarke, G.K.C., 1998. Layered granodiorites at Chebucto Head, South Mountain batholith, Nova Scotia. Journal of Structural Geology 20, 1305-1324.

Clemens, J.D., 2003. S-type granites - petrogenetic issues, models and evidence. Earth-Science Reviews 61, 1-18.

Edelman, N., 1972. A porphyroblastic granite with preserved bedding. Geologiska Föreningens i Stockholm Förhandlingar 94, 193-211.

Ehlers, C., Lindroos, A. \& Selonen, O., 1993. The late Svecofennian granite-migmatite zone of southern Finland a belt of transpressive deformation and granite emplacement. Precambrian Research 64, 295-309.

Eklund, O., Konopelko, D., Rutanen, H., Fröjdö, S. \& Shebanov, A.D., 1998. 1.8 Ga Svecofennian post-collisional shoshonitic magmatism in the Fennoscandian Shield. Lithos 45, 87-108.

Eliasson, T., Ahlin, S. \& Peterson, J., 2003. Emplacement mechanism and thermobarometry of the Sweconorwegian Bohus granite, SW Sweden. GFF 125, 113-130.

Härme, M., 1965. On the potassium granites of southern Finland. Bulletin de la Commission Géologique de Finlande 219, $43 \mathrm{p}$.

Holdaway, M.J., 2000. Application of new experimental and garnet Margules data to the garnet-biotite geothermometer. American Mineralogist 85, 881-892.
Huhma, H., 1986. Sm-Nd, U-Pb and Pb-Pb isotopic evidence for the origin of the Early Proterozoic Svecokarelian crust in Finland. Geological Survey of Finland, Bulletin 337, $48 \mathrm{p}$.

Johannes, W., Ehlers, C., Kriegsman, L.M. \& Mengel, K., 2003. The link between migmatites and S-type granites in the Turku area, southern Finland. Lithos 68, 69-90.

Jurvanen, T., Eklund, O. \& Väisänen, M., 2005. Generation of A-type granitic melts during the late Svecofennian metamorphism in southern Finland. Geologiska Föreningens I Stockholm Förhandlingar 127, 139-147.

Korsman, K., Koistinen, T., Kohonen, J., Wennerström, M., Ekdahl, E., Honkamo, M., Idman, H., Pekkala, Y. (eds), 1997. Suomen kallioperäkartta - Berggrundskarta över Finland - Bedrock map of Finland 1: 1000 000. Geological Survey of Finland, Espoo, Finland.

Kosunen, P., 1999. The rapakivi granite plutons of Bodom and Obbnäs, southern Finland: petrography and geochemistry. Bulletin of the Geological Society of Finland 71, 275-304.

Kurhila, M., Vaasjoki, M., Mänttäri, I., Rämö, T. \& Nironen, M., 2005. U-Pb ages and $\mathrm{Nd}$ isotope characteristics of the lateorogenic, migmatizing microcline granites in southwestern Finland. Bulletin of the Geological Society of Finland 77, 105-128.

Lahtinen, R. 1996. Geochemistry of Palaeoproterozoic supracrustal and plutonic rocks in the Tampere-Hämeenlinna area, southern Finland. Geological Survey of Finland, Bulletin 389, 113 p.

Lahtinen, R., Korja, A. \& Nironen, M., 2005. Paleoproterozoic tectonic evolution. In: Lehtinen, M., Nurmi, P.A. \& Rämö, O.T. (eds). Precambrian Geology of Finland - Key to the Evolution of the Fennoscandian Shield. Developments in Precambrian Geology, Volume 14. Elsevier, Amsterdam, 481-531.

Laitala, M., 1960. Siuntio. Geological Map of Finland 1:100 000, pre-Quaternary rocks, sheet 2032, Geological Survey of Finland.

Laitala, M., 1994. Lohja. Geological Map of Finland 1:100 000, pre-Quaternary rocks, sheet 2041, Geological Survey of Finland.

Montel, J.-M. \& Vielzeuf, D., 1997. Partial melting of metagreywackes, Part II. Compositions of minerals and melts. Contributions to Mineralogy and Petrology 128, 176-196.

Mouri, H., Väisänen, M., Huhma, H. \& Korsman, K., 2005. $\mathrm{Sm}-\mathrm{Nd}$ garnet and $\mathrm{U}-\mathrm{Pb}$ monazite dating of high-grade metamorphism and crustal melting in the West Uusimaa area, southern Finland. GFF 127, 123-128.

Nironen, M., 2005. Proterozoic orogenic granitoid rocks. In: Lehtinen, M., Nurmi, P.A. \& Rämö, O.T. (eds). Precambrian Geology of Finland - Key to the Evolution of the Fennoscandian Shield. Developments in Precambrian Geology, Volume 14. Elsevier, Amsterdam, 443-479.

Nironen, M., Korja, A., Heikkinen, P. \& FIRE Working Group, 2006. A geological interpretation of the up- 
per crust along FIRE 2 and 2A. In: Kukkonen, I.T. \& Lahtinen, R. (eds). Finnish Reflection Experiment FIRE 2001-2005. Geological Survey of Finland, Special Paper 43, 77-104.

Nurmi, P.A. \& Haapala, I., 1986. The Proterozoic granitoids of Finland: granite types, metallogeny, and relation to crustal evolution. Bulletin of the Geological Society of Finland 58, 203-233.

Parras, K., 1958. On the charnockites in the light of a highly metamorphic rock complex in southwestern Finland. Bulletin de la Commission Géologique de Finlande 181, $137 \mathrm{p}$.

Patiño Douce, A.E. \& Johnston, A.D., 1991. Phase equilibria and melt productivity in the pelitic system: implications for the origin of peraluminous granitoids and aluminous granulites. Contributions to Mineralogy and Petrology 107, 202-218.

Patiño Douce, A.E. \& Beard, J.S., 1995. Dehydration melting of biotite gneiss and quartz amphibolite from 3 to 15 kbar. Journal of Petrology 36, 707-738.

Pyle, J.M. \& Spear, F.S., 1999. Yttrium zoning in garnet: coupling of major and accessory phases during metamorphic reactions. Geological Materials Research 1, 1-49.

Schreurs, J. \& Westra, L., 1986. The thermotectonic evolution of a Proterozoic, low pressure, granulite dome, West Uusimaa, SW Finland. Contributions to Mineralogy and Petrology 93, 236-250.

Selonen, O., Ehlers, C. \& Lindroos, A., 1996. Structural features and emplacement of the late Svecofennian Perniö granite sheet in southern Finland. Bulletin of the Geological Society of Finland 68, 5-17.

Simonen, A., 1980. The Precambrian of Finland. Geological Survey of Finland, Bulletin 304, 58 p.

Skyttä, P. \& Mänttäri, I., 2008. Structural setting of late Svecofennian granites and pegmatites in Uusimaa Belt, SW Finland: Age constraints and implications for crustal evolution. Precambrian Research (in press).

Skyttä, P., Väisänen, M. \& Mänttäri, I., 2006. Preservation of Palaeoproterozoic early Svecofennian structures in the Orijärvi area, SW Finland - evidence for polyphase strain partitioning. Precambrian Research 150, 153-172.

Stålfors, T. \& Ehlers, C., 2006. Emplacement mechanisms of late-orogenic granites: structural and geochemical evidence from southern Finland. International Journal of Earth Science 95, 557-568.

Suominen, V., 1991. The chronostratigraphy of southwestern Finland, with special reference to Postjotnian and Subjotnian diabases. Geological Survey of Finland, Bulletin 356, 100 p.

Vaasjoki, M., 1996. Explanation to the geochronological map of southern Finland: The development of the continental crust with special reference to the Svecofennian orogeny. Geological Survey of Finland, Report of Investigation $135,30 \mathrm{p}$.

Väisänen, M. \& Hölttä, P., 1999. Structural and metamorphic evolution of the Turku migmatite complex, south- western Finland. Bulletin of the Geological Society of Finland 71, 177-218.

Väisänen, M., Mänttäri, I., Kriegsman, L.M. \& Hölttä, P., 2000. Tectonic setting of post-collisional magmatism in the Palaeoproterozoic Svecofennian Orogen. Lithos 54, 63-81.

Väisänen, M., Mänttäri, I. \& Hölttä, P., 2002. Svecofennian magmatic and metamorphic evolution in southwestern Finland as revealed by U-Pb zircon SIMS geochronology. Precambrian Research 116, 111-127.

Vielzeuf, D. \& Holloway, J.R., 1988. Experimental determination of the fluid-absent melting relations in the pelitic system. Contributions to Mineralogy and Petrology 98, 257-276.

Vielzeuf, D. \& Montel, J.M., 1994. Partial melting of metagreywackes. Part I. Fluid-absent experiments and phase relationships. Contributions to Mineralogy and Petrology $117,375-393$.

Watson, E.B. \& Harrison T.M., 1983. Zircon saturation revisited: temperature and composition effects in a variety of crustal magma types. Earth and Planetary Science Letters 64, 295-304.

Wu C.M., Zhang J. \& Ren L.D., 2004. Empirical garnet-biotite-plagioclase-quartz (GBPQ) geobarometry in medium- to high-grade metapelites. Journal of Petrology 45, 1907-1921. 


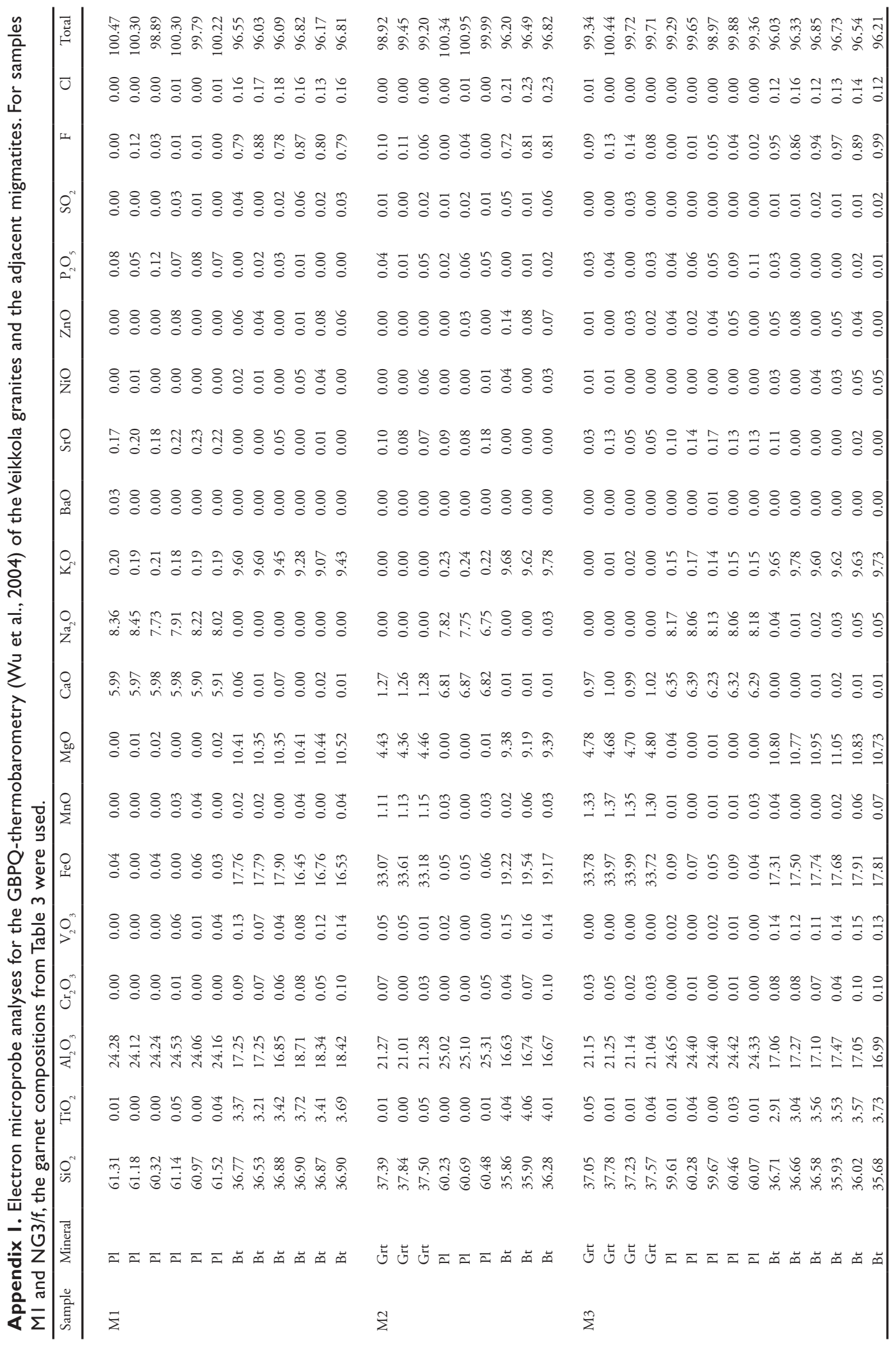




\begin{tabular}{|c|c|c|c|}
\hline 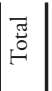 & 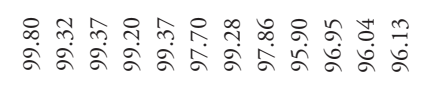 & 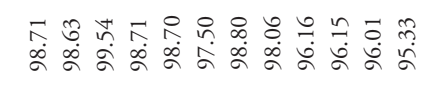 & 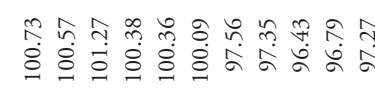 \\
\hline jo & 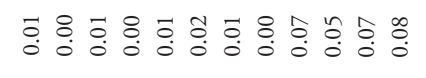 & 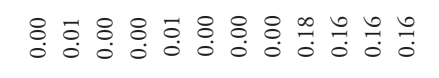 & 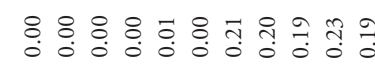 \\
\hline I & 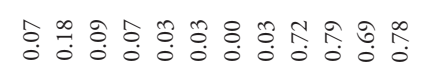 & 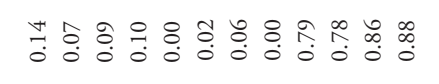 & 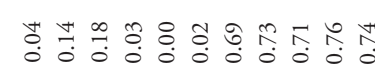 \\
\hline$\infty^{2}$ & 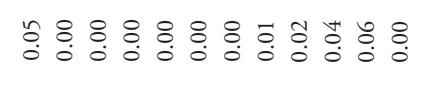 & 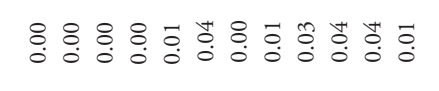 & 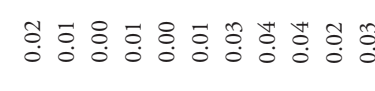 \\
\hline $0^{n}$ & 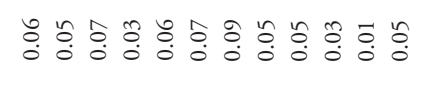 & 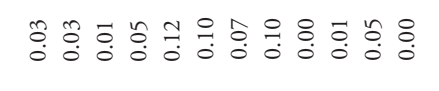 & 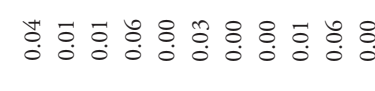 \\
\hline ○ & 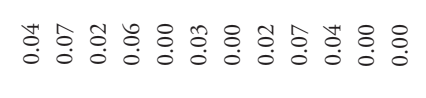 & 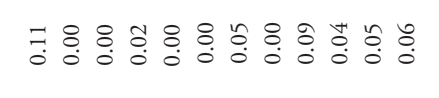 & 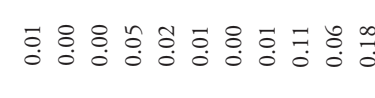 \\
\hline$\stackrel{0}{\circ}$ & $\because$ & 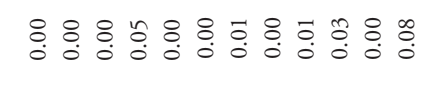 & 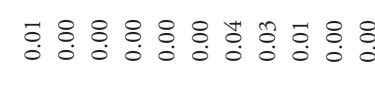 \\
\hline o & 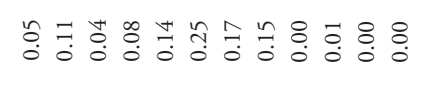 & 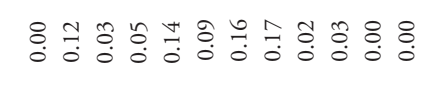 & 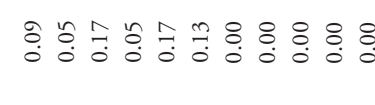 \\
\hline$\underset{\mathscr{q}}{O}$ & : & 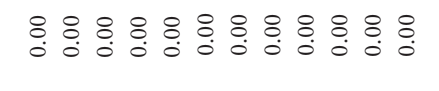 & 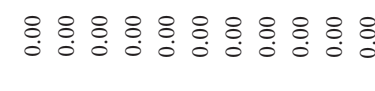 \\
\hline \begin{tabular}{c}
0 \\
\hdashline
\end{tabular} & 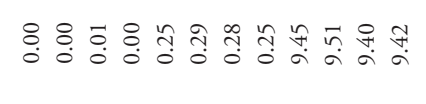 & 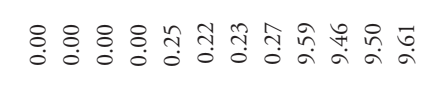 & 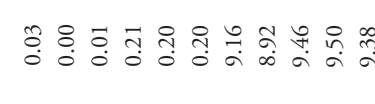 \\
\hline $\begin{array}{c}0 \\
\tilde{z}^{n}\end{array}$ & 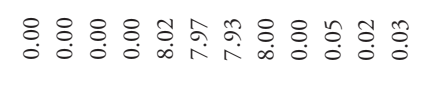 & 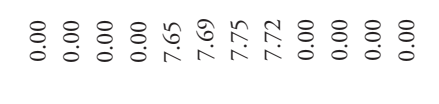 & 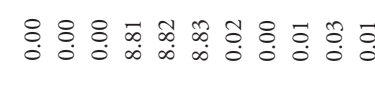 \\
\hline O & 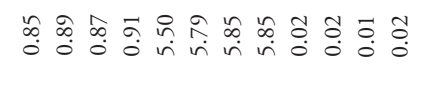 & 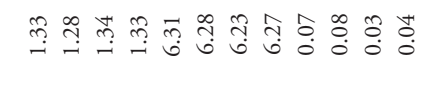 & 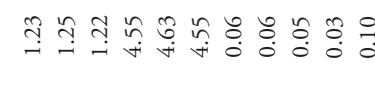 \\
\hline$\underset{\substack{\infty \\
2}}{\infty}$ & 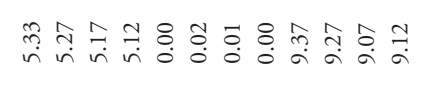 & 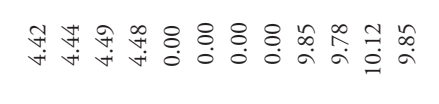 & 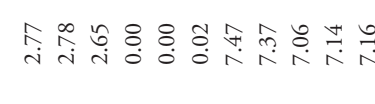 \\
\hline$\stackrel{\circ}{\Xi}$ & 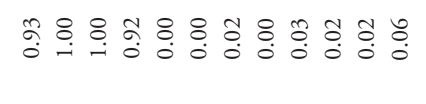 & 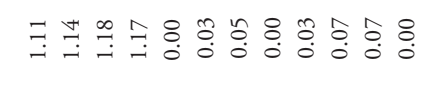 & 伞 \\
\hline 里 & 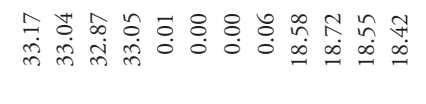 & 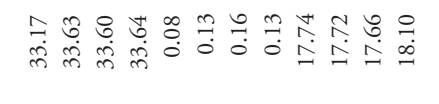 & 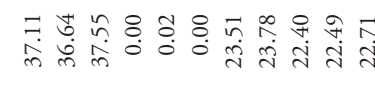 \\
\hline $0_{N}^{m}$ & 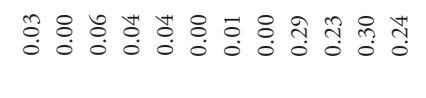 & 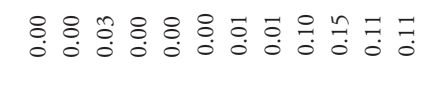 & 菅 \\
\hline $0^{m}$ & 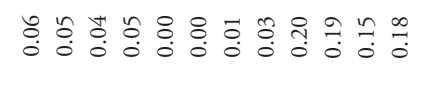 & 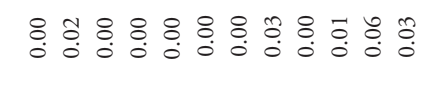 & 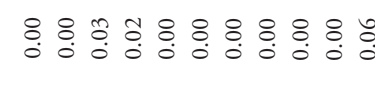 \\
\hline $0^{m}$ & 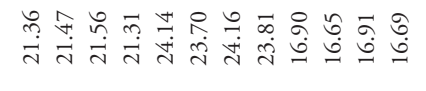 & 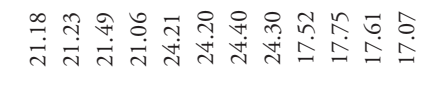 & 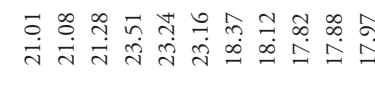 \\
\hline $0^{\sim}$ & 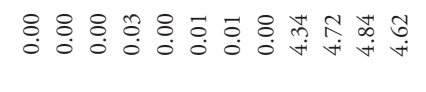 & 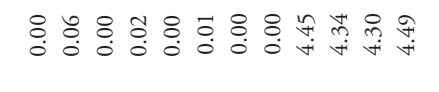 & 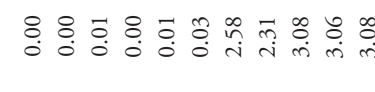 \\
\hline $0^{\sim}$ & 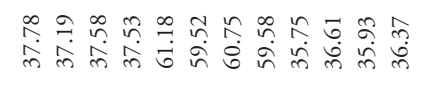 & 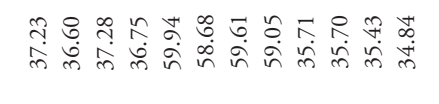 & 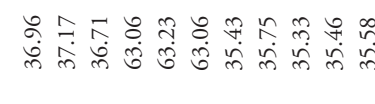 \\
\hline . & 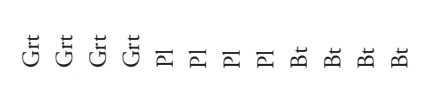 & 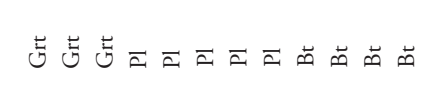 & 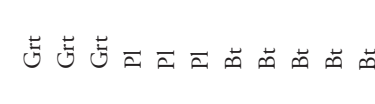 \\
\hline & $\frac{\pi}{\Sigma}$ & $\stackrel{\vec{W}}{\vec{r}}$ & $\begin{array}{l}\mathscr{J} \\
z\end{array}$ \\
\hline
\end{tabular}




\begin{tabular}{|c|c|c|c|c|}
\hline قِ & 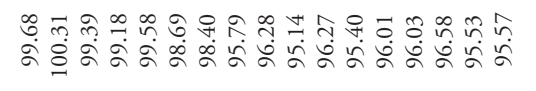 & 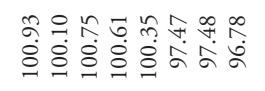 & 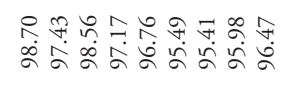 & å \\
\hline jo & : & 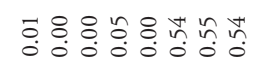 & 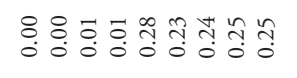 & 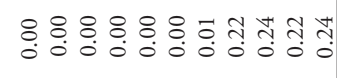 \\
\hline 工 & 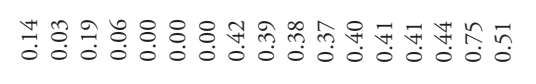 & 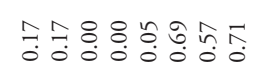 & 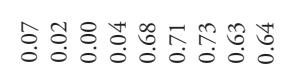 & 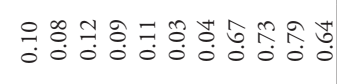 \\
\hline$\infty^{2}$ & 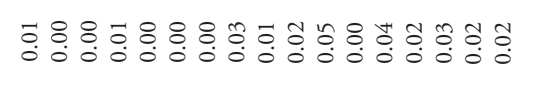 & : & 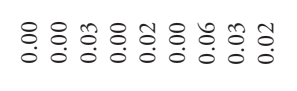 & 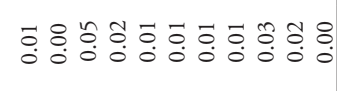 \\
\hline $0^{n}$ & 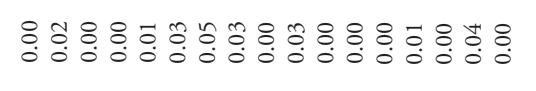 & 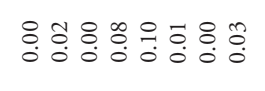 & 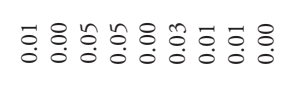 & 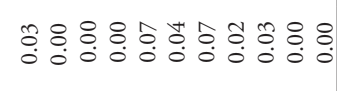 \\
\hline 号 & 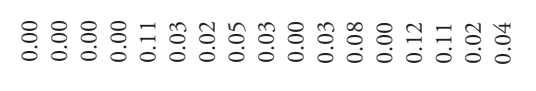 & 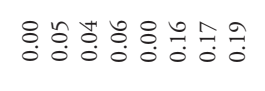 & 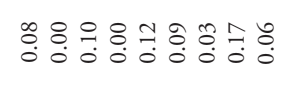 & 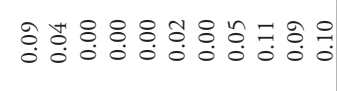 \\
\hline 高 & 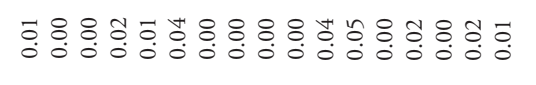 & 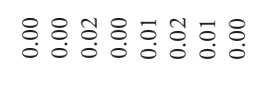 & 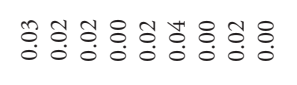 & 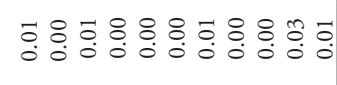 \\
\hline 官 & 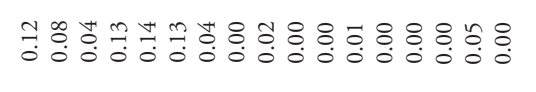 & 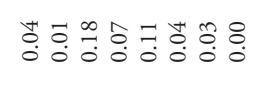 & 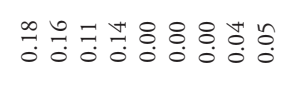 & 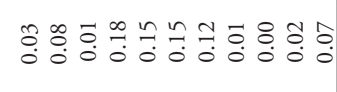 \\
\hline$\underset{\varnothing}{0}$ & 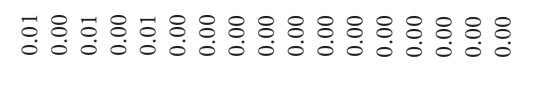 & $\therefore: 8: 8: 8:$ & 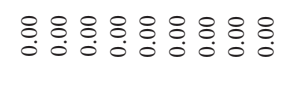 & $8: 8: 8: 00: 0$ \\
\hline $\begin{array}{l}0 \\
1 \\
1\end{array}$ & 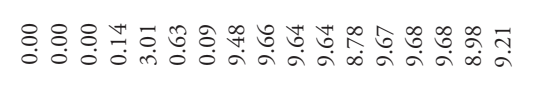 & 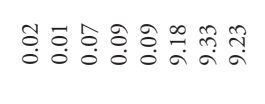 & 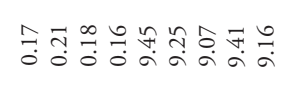 & 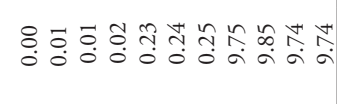 \\
\hline $\int_{j}^{0}$ & 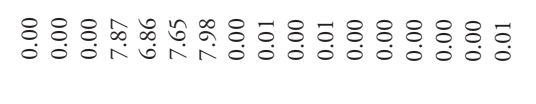 & 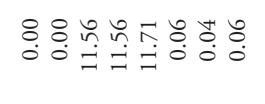 & $8: 8:-5$ & - l \\
\hline O & 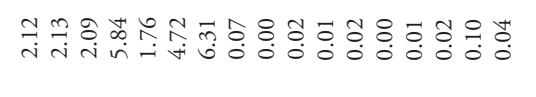 & 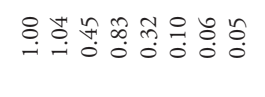 & 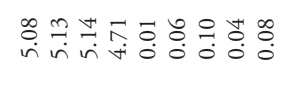 & 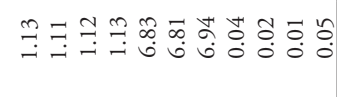 \\
\hline$o_{a}$ & 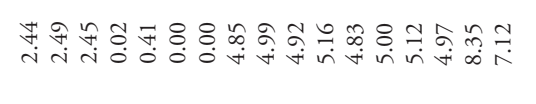 & 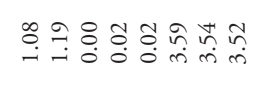 & 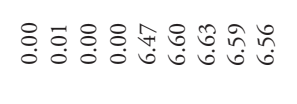 & 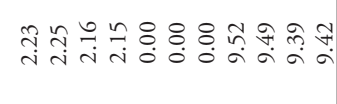 \\
\hline${ }_{g}$ & $\vec{a}: \begin{array}{l}0 \\
\vdots\end{array}:$ & 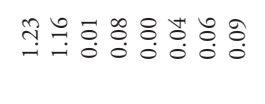 & 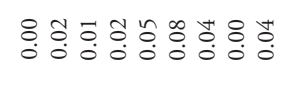 & 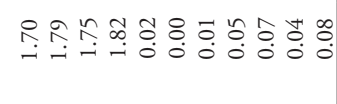 \\
\hline 集 & 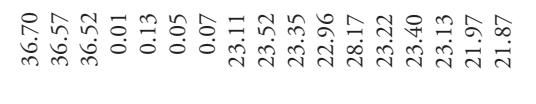 & 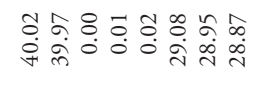 & 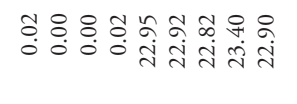 & 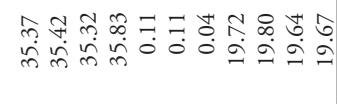 \\
\hline $0^{\infty}$ & 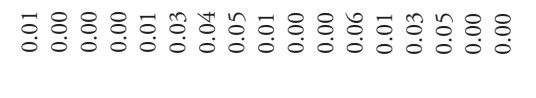 & 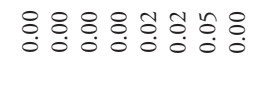 & 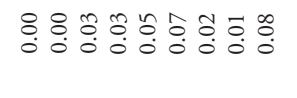 & ¿̂: \\
\hline$O^{n}$ & 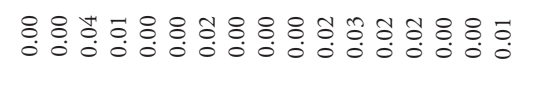 & 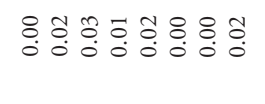 & 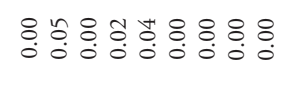 & 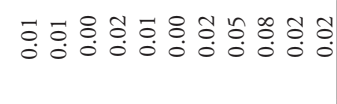 \\
\hline $0^{\infty}$ & 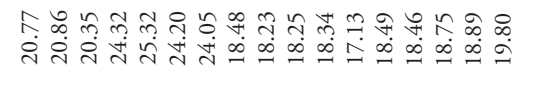 & 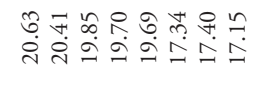 & 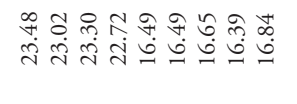 & 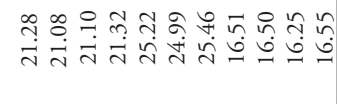 \\
\hline $0^{\circ}$ & 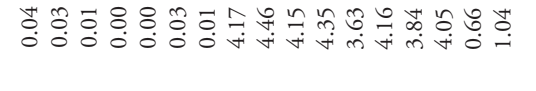 & 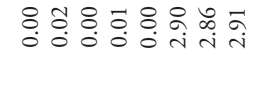 & 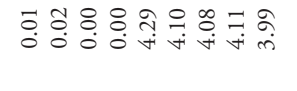 & 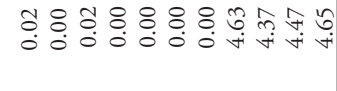 \\
\hline $0_{0}^{0}$ & 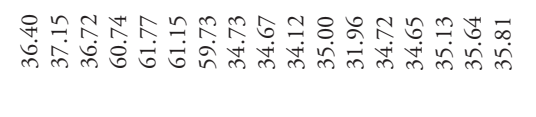 & 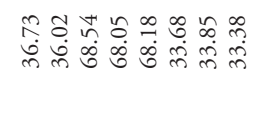 & 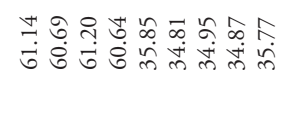 & Sุ \\
\hline & 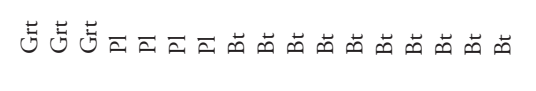 & 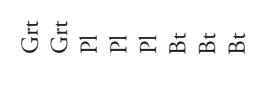 & 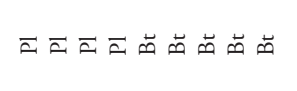 & 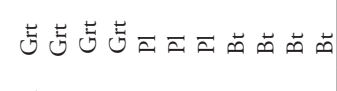 \\
\hline & & 式 & $\overline{\mathrm{B}}$ & तु \\
\hline
\end{tabular}




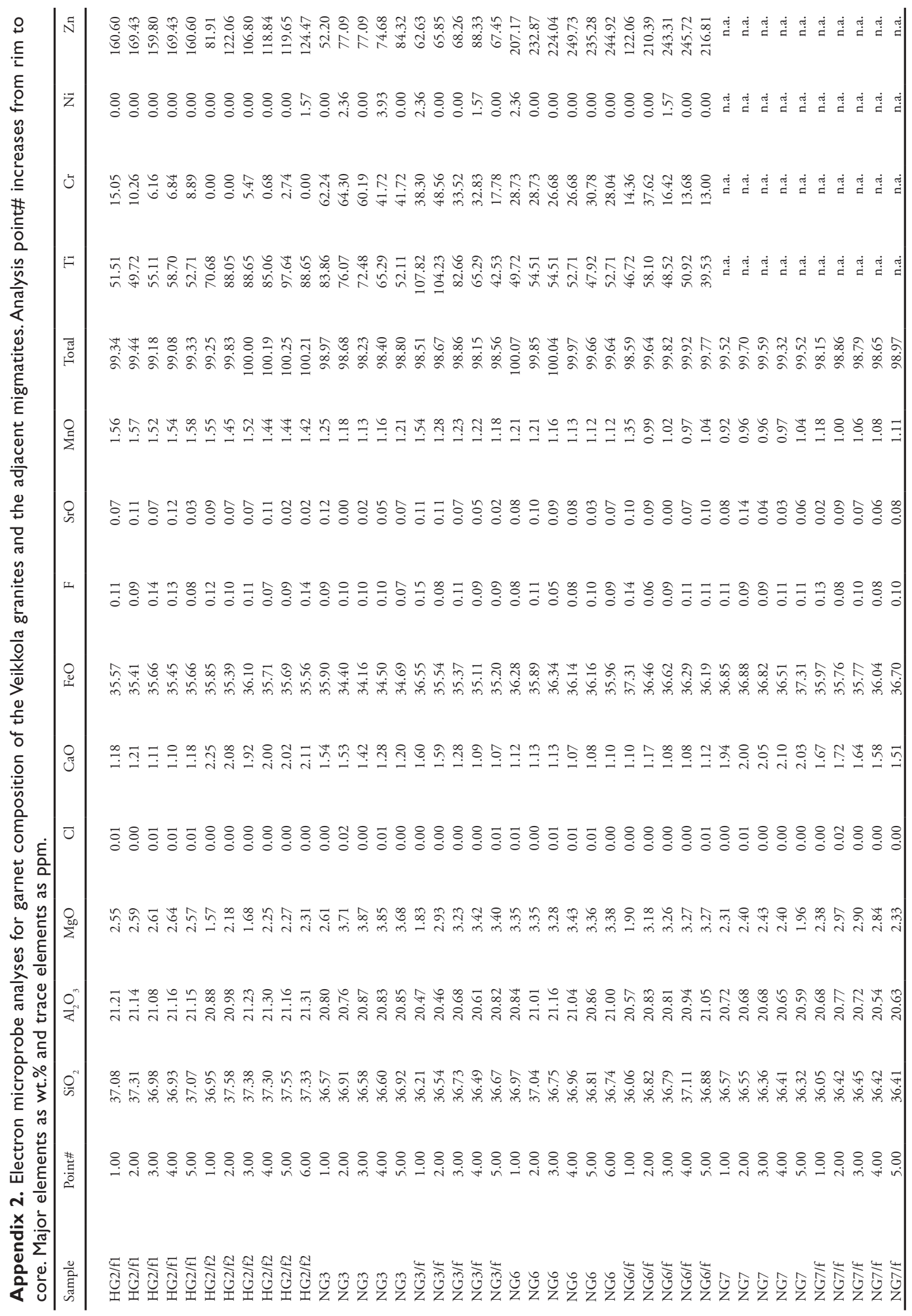




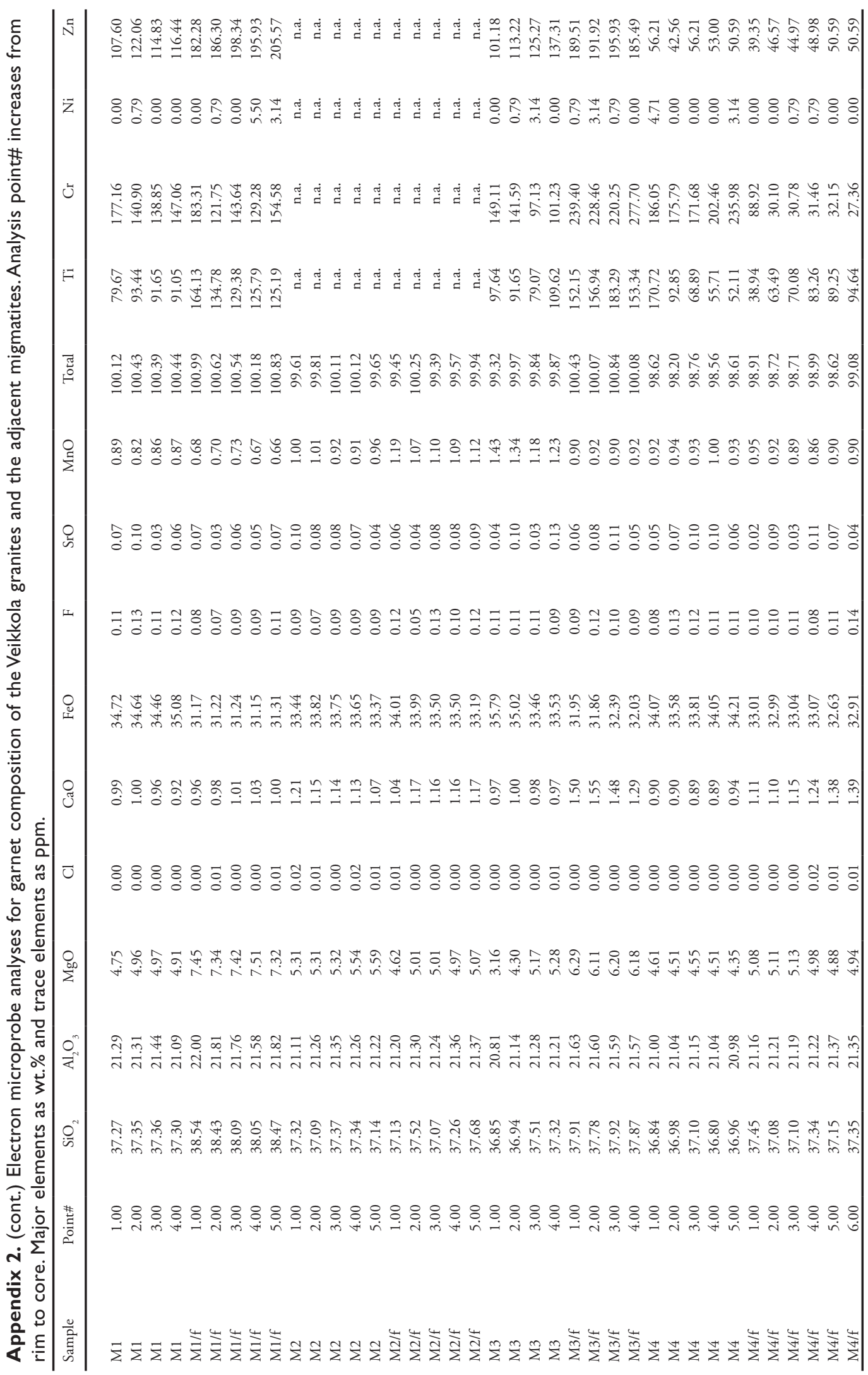

